\title{
Hydrogeological properties of fault zones in a karstified carbonate aquifer (Northern Calcareous Alps, Austria)
}

\author{
H. Bauer ${ }^{1}$ (I) - T. C. Schröckenfuchs ${ }^{1} \cdot$ K. Decker ${ }^{1}$
}

Received: 17 July 2015 / Accepted: 14 February 2016 / Published online: 12 March 2016

(C) The Author(s) 2016. This article is published with open access at Springerlink.com

\begin{abstract}
This study presents a comparative, field-based hydrogeological characterization of exhumed, inactive fault zones in low-porosity Triassic dolostones and limestones of the Hochschwab massif, a carbonate unit of high economic importance supplying $60 \%$ of the drinking water of Austria's capital, Vienna. Cataclastic rocks and sheared, strongly cemented breccias form low-permeability $(<1 \mathrm{mD})$ domains along faults. Fractured rocks with fracture densities varying by a factor of 10 and fracture porosities varying by a factor of 3 , and dilation breccias with average porosities $>3 \%$ and permeabilities $>1,000 \mathrm{mD}$ form high-permeability domains. With respect to fault-zone architecture and rock content, which is demonstrated to be different for dolostone and limestone, four types of faults are presented. Faults with single-stranded minor fault cores, faults with single-stranded permeable fault cores, and faults with multiple-stranded fault cores are seen as conduits. Faults with single-stranded impermeable fault cores are seen as conduit-barrier systems. Karstic carbonate dissolution occurs along fault cores in limestones and, to a lesser degree, dolostones and creates superposed highpermeability conduits. On a regional scale, faults of a particular deformation event have to be viewed as forming a network of flow conduits directing recharge more or less rapidly towards the water table and the springs. Sections of
\end{abstract}

Electronic supplementary material The online version of this article (doi:10.1007/s10040-016-1388-9) contains supplementary material, which is available to authorized users.

H. Bauer

helene.bauer@univie.ac.at

1 Department of Geodynamics and Sedimentology, University of Vienna, Althanstraße 14, 1090 Vienna, Austria impermeable fault cores only very locally have the potential to create barriers.

Keywords Fractured rocks · Carbonate rocks · Fault zones · Hydrogeological properties · Austria

\section{Introduction}

Fault zones in the upper crust produce permeability heterogeneities that have a large impact on subsurface fluid migration and storage patterns (e.g. Agosta et al. 2010, 2012; Caine et al. 1996; Faulkner et al. 2010; Jourde et al. 2002; Mitchell and Faulkner 2012; Shipton and Cowie 2003; Shipton et al. 2006; Wibberley and Shimamoto 2003; Wibberley et al. 2008). In shallow crustal depths, primary deformation mechanisms such as cataclasis, deformation banding, brecciation and fracturing are similar for crystalline, siliciclastic and carbonate rocks, but water-rock interaction in carbonates has the potential to generate completely different permeability characteristics impacting fluid flow in aquifers (e.g. Kim and Sanderson 2009; Micarelli et al. 2006). The present study investigates the structural and hydraulic characteristics of fault zones in a low-porosity carbonate and their potential impact on regional aquifer systems charging springs of major importance.

Faults reveal a wide range of hydraulic behaviours, acting as conduits, barriers or mixed conduit-barrier systems (Aydin 2000; Bense et al. 2013 for full reviews; Caine et al. 1996; Faulkner et al. 2010). The hydraulic behaviour of fault zones is governed by initial host-rock composition, deformation mechanisms working during fault-zone evolution, fault-zone architecture and alteration of fault zones (e.g. dissolution weathering). The standard fault core-damage zone model (Billi et al. 2003; Caine et al. 1996; Chester et al. 1993; Rawling et al. 2001) is still widely used, although it was 
demonstrated by many authors that it oversimplifies the actual complexity of fault zones (e.g. Bonson et al. 2007; Childs et al. 2009; Faulkner et al. 2010). Distribution, quantity, and connectivity of different fault components strongly influence permeability and may vary across and along fault strike, and over time (Lunn et al. 2008; Petracchini et al. 2012; Schulz and Evans 2000; Shipton and Cowie 2001). Processes like fault-segment linkage and interaction explain some of these observed complex fault geometries (e.g. Bonson et al. 2007; Childs et al. 2009; Faulkner et al. 2010; Kim and Sanderson 2009; Lunn et al. 2008). A long-lived history of progressive deformation can be expected to lead to a more complex buildup of faults with potentially asymmetric permeability structures (Wibberley and Shimamoto 2003). Fault-zone thickness shows a clear positive correlation with displacement (Bense et al. 2013; Childs et al. 2009) but is strongly depending on the overall deformation history (Savage and Brodsky 2011; Shipton et al. 2006 and references cited there).

Fault-zone hydrogeological properties in crystalline and siliciclastic rocks have been studied extensively (e.g. Bense and Person 2006; Bense et al. 2013 for full reviews; Faulkner et al. 2008; Leray et al. 2013; Mitchell and Faulkner 2008, 2009), since these rocks host some of the world's most active large faults or important hydrocarbon reservoirs. In crystalline rocks, fault cores contain breccias and gouges of strongly reduced permeability along the principal slip plane, whereas fractured rocks of the damage zones form permeable conduits oriented parallel to the fault plane (Caine et al. 1996). Fault zones in high-porosity siliciclastic rocks exhibit cataclastic fault cores with permeabilities reduced by up to 2-3 orders of magnitude (Balsamo and Storti 2010). Damage-zone permeability is influenced and governed by deformation-band networks, that display zones of reduced permeability (Rath et al. 2011; Storti et al. 2003), and fractures that enhance damage-zone permeability (Eichhubl et al. 2009).

There is vast literature on carbonate fault zones that are generally characterized by wide zones of fractured rock (distributed strain) and narrow zones of fault rocks (zones of localized strain; Aydin 2000; Bense et al. 2013 for full reviews; Faulkner et al. 2010). However, the subsurface hydrogeological behaviour of faults in carbonate aquifers is very difficult to determine (e.g. Celico et al. 2006) as water/rock interactions (dissolutional weathering) produce transient, heterogeneous and anisotropic permeability structures (Agosta et al. 2007; Agosta 2008).

Within high-porosity carbonates (Antonellini et al. 2014; Billi et al. 2003, 2007; Billi and Storti 2004; Billi 2005a; Micarelli et al. 2006), pore collapse, grain crushing, rotationenhanced abrasion and calcite precipitation within cataclastic rocks in the fault core lead to a significant porosity reduction. In addition, deformation banding and stylolite formation reduce permeability within the damage zone (Tondi et al. 2006).

Fault cores within low-porosity carbonates contain cataclastic fault rocks with low porosity and permeability (e.g. Agosta and Kirschner 2003; Agosta et al. 2007; Agosta
2008; Billi and Di Toro 2008; Billi et al. 2008; Storti et al. 2003). In the damage zone, porosity and permeability are expected to increase and are controlled by connectivity and anisotropy of fracture networks (Agosta et al. 2010; Billi 2005b) and/or breccia zones (e.g. Billi 2005a; Hausegger et al. 2010; Tarasewicz et al. 2005).

The quantification of this fracture-related porosity and permeability poses a major challenge, since individual fracture characteristics such as length, spacing, aperture, orientation, connectivity and distribution may vary over short distances, depth and time. Fault zones containing large volumes of damage-zone rock and comparably small volumes of cataclastic fault-core act as first-order permeability features within carbonate reservoirs (Guerriero et al. 2010). Statistical analysis of fractures using scan line techniques (e.g. Agosta et al. 2010; Billi 2005b; Guerriero et al. 2010; Guerriero et al. 2013; Korneva et al. 2014) show that fracture arrays in unfaulted host-rocks are usually more isotropic, whereas fracture arrays within fault damage zones are characterized by anisotropies. Fracture aperture and fracture connectivity is controlling the permeability in fractured media, resulting in either extremely channelized or more distributed flow paths (e.g. de Dreuzy et al. 2002). Breccias, resulting from various deformation processes like rock pulverization (Dor et al. 2006; Mitchell et al. 2011), or hydro fracturing (Tarasewicz et al. 2005) may cause permeability enhancements of up to 4 or 5 orders of magnitude (Walker et al. 2013), while, on the other hand, cementation due to the interaction with fluids (e.g. Agosta et al. 2012; Baqués et al. 2010; Micarelli et al. 2006) and/or shearing will result in a reduction of permeability.

This study focuses on the hydrogeological characterization of inactive fault zones located in a carbonate karst plateau (Hochschwab massif) of major hydrogeological importance, since the area supplies around $60 \%$ of the drinking water for Austria's capital, Vienna. Karst features and springs in the area have been investigated and monitored intensely over the last years (see unpublished report by Decker in Table 1; Decker and Reiter 2001; Kuschnig 2009; Plan 2002, 2005; Plan and Decker 2006; Plan et al. 2009, 2010). Surface karstification features and caves are preferentially following fault zones of a certain deformation stage (see unpublished report by Decker in Table 1; Plan and Decker 2006). The detailed hydrogeological properties of fault zones are poorly known. The objective of this study is to characterize and classify a number of typical fault zones in this area with respect to architectural build-up, fault-core and damagezone thickness, type and extent of fault rocks and their hydraulic properties, damage-zone fracture densities and karstification of fault zones. In a more regional context, the potential impact of these fault zones on the behaviour of the karst-water system will be discussed. 
Table 1 Unpublished reports associated with this study

Author/s and affiliation/s

Bauer F

Decker K

University of Vienna,

Department for Geodynamics and Sedimentology

Mandl G, Bryda G, Kreuss O, Moser M, Pavlik W. Geological Survey of Austria,

Department Sedimentary Geology

Stadler H, Strobl E

Joanneum Research, Forschungsgesellschaft mbH, Institute for Water Resources
Title (with English translation) and details

Bericht über den im Auftrag des Bundesministeriums für Land und Forstwirtschaft durchgeführten Markierungsversuch, Hochschwab, 1971 (Report to the federal ministry of agriculture and forestry regarding a tracer test at the Hochschwab, 1971). Vienna, Speleologic Institute (1972)

Tektonik/Strukturgeologische Grundlagen (Tectonics/ structural geology).

In: Mandl et al.(ed) Karstwasserdynamik und Karstwasserschutz Hochschwab: Geologische Karte (Karst water dynamics and protection in the Hochschwab: Geological map). Folgeprojekt Hochschwab West \& Süd WA4A/ F1998 \& StA028n. Geol Surv Austria, Vienna. (2000)

Erstellung moderner geologischer Karten als Grundlage für karsthydrogeologische Spezialuntersuchungen im Hochschwabgebiet (Creating modern geological maps of the Hochschwab to the use in karst hydrogeological investigations).

Report to the Viennese Waterworks, Geol. Survey, Vienna. (2002)

Hydrogeologie Hochschwab Zusammenfassung (Hydrogeology of the Hochschwab: summary).

Joanneum Research, Graz, Austria (2006)

\section{Study area}

\section{Geological setting}

The Hochschwab massif is part of the Northern Calcareous Alps (NCA; see Fig. 1a), a 3-5 km thick, non-metamorphic, Permo-Mesozoic sedimentary succession (Tollmann 1976). Together with weakly metamorphosed Paleozoic sequences, the NCA form the Austroalpine cover nappes (Linzer et al. 2002). The stratigraphic sequences within the Hochschwab massif (see Fig. 1b) comprise Permian to Late Triassic sediments of 2,000-m total thickness (Mandl et al. 2000; see unpublished report by Mandl et al. in Table 1) with Werfen Fm., Gutenstein Fm. and Steinalm Fm. making up the stratigraphic basis of the succession. Sandstones and shales of the Lower Triassic Werfen Formation build the basis of the carbonate strata, the Werfen shales and/or Paleozoic shists acting as regional aquitards. The calcareous strata reflect facies differentiation since Anisian times resulting in the development of carbonate platforms (dolostones and limestones of the Steinalm and Wetterstein Fm. in the central and northern Hochschwab massif) and of reef, slope and basinal limestones (Wettertstein Fm., Grafensteig Fm., Sonnschien Fm., Tremmelgarben Fm.; Fig. 1b; Bryda 2001; see unpublished report by Mandl et al. in Table 1).

Five stages of deformation (D1-D5) are identified in the Hochschwab massif (see unpublished report by Decker in Table 1), the most important being (1) NW-directed dextral transpressional stacking of nappes during the Late-Early Cretaceous to late Eocene, (2) N-directed thrusting (EoceneOligocene) and (3) eastward lateral extrusion of crustal wedges along (E)NE-striking sinistral strike-slip faults such as the SEMP (Salzach-Ennstal-Mariazell-Puchberg fault zone) during the Miocene (Decker et al. 1994; Linzer et al. 1995)

The investigated fault zones are all part of the SEMP, which is $400 \mathrm{~km}$ long and crosses all Austroalpine tectonostratigraphic units (Decker et al. 1994; Linzer et al. 1995, 2002; Peresson and Decker 1997; Ratschbacher et al. 1991), forming the lateral ramp of the eastward extrusion of the Eastern Alps in the course of the post-collisional exhumation of the Tauern window (Linzer et al. 2002) (Fig. 1a). The central and eastern portions of the SEMP are characterized by brittle deformation (Frost et al. 2009, 2011) with a total displacement of about $40 \mathrm{~km}$ (Linzer et al. 2002). In the Hochschwab massif the SEMP forms a restraining bend characterized by sinistral transpressional strike-slip duplexes and compressional flower structures (see unpublished report by Decker in Table 1) (Fig. 1b).

\section{Hydrogeological context}

The main Hochschwab plateau, with the summit at 2, $277 \mathrm{~m}$ asl, covers around $83 \mathrm{~km}^{2}$ and is bounded by steep valleys (valley floors at 500-700 m asl). Annual precipitation in the plateau area amounts to $2,200 \mathrm{~mm} /$ year. Numerous highly productive springs, located on the $\mathrm{N}$ and NE slope of the Hochschwab massif, provide around $60 \%$ of the Viennese drinking water (Kuschnig 2009). The present study focuses on the catchment area of two of these springs, the Kläffer spring and the Pfannbauern spring, where limestones and dolostones, respectively, are exposed.

The Kläffer spring is the biggest spring in the Eastern Alps with a maximum discharge of $34 \mathrm{~m}^{3} / \mathrm{s}$, measured after a thunderstorm event. The discharge ratio calculated from daily means over the year 2011 gives a discharge ratio of 13 
(Fig. 1d), indicative for a low storage capacity of the aquifer. The Kläffer spring emerges along a N-S trending strike-slip fault, which cuts and connects several E-W trending faults in well-bedded intraplatform basinal limestones (Tremmelgraben Fm.) almost at the lowest point of the karst aquifer (Plan et al. 2010). In fact, the Kläffer spring consists of several springs ranging in elevation from 650 to $750 \mathrm{~m}$ asl, with the higher springs being active only during periods of high discharge. All these springs are fed by the same karstwater body (see unpublished report by Stadler and Strobl in Table 1). Based on mass-balance calculations, the assumed catchment of the Kläffer spring has an area of around 57$70 \mathrm{~km}^{2}$ (Nachtnebel et al 2012; Plan et al. 2010, see unpublished report by Stadler and Strobl in Table 1), which corresponds roughly to the main Hochschwab plateau. The mean residence time calculated from an exponential model with tritium data is $0.8-1.5$ years (see unpublished report by Stadler and Strobl in Table 1).

The plateau shows intense karstification with karst features at various scales, including dolines, small poljes and caves. Field mapping revealed a total of more than 7,000 dolines (Plan 2002; Plan and Decker 2006). Poljes developed on top of uplifted shales and sandstones of the Werfen Fm., and more than 600 caves, which are typically vadose canyons, are documented, proving a karst water table below 1,000 m asl (Plan 2005).

A single tracer test (unpublished report by Bauer, see Table 1) using Uranin injected in a large doline in the NE part of the plateau (Fig. 1c) indicated an E-W directed drainage pattern parallel to the topography of the massif and towards the northern slope of the plateau. This is in accordance with surface karst features at the plateau showing a preferred ENEWSW strike (Plan and Decker 2006), following faults formed by the D3 deformation stage (Decker and Reiter 2001).

During the initial stages of field work, a preliminary screening of faults was performed on a regional scale. Based on criteria such as location, accessibility and outcrop conditions, a selection of candidates for further field work was established. A representative spectrum of fault widths and deformation intensities is covered by the selected faults. The $\mathrm{N}-\mathrm{S}$-trending Ring Valley is cut by several closely spaced strike-slip faults (horizontal distances of 300-500 m), belonging to the $\mathrm{D} 3$ deformation phase that can be tracked vertically over several hundred meters. The outcrops are located at an elevation of around $1,000 \mathrm{~m}$ asl. This offered the possibility to focus on fault characteristics relatively close to the karst water table and the Kläffer spring and to confirm whether structural features in the area created by the D3 faulting act as potential conduits. In addition, the fault A5 in the Brunntal Valley at a similar elevation has been chosen to clarify whether a much thicker fault core could potentially make the fault zone act as a hydrogeological barrier.

Since the Hochschwab contains significant volumes of dolostones, two D3 faults located in dolostones of the
Fig. 1 a Simplified tectonic map of the Eastern Alps showing the Northern Calcareaous Alps and some of the major faults including the SEMP fault system, which is of great importance for the area of investigation. b Geological map of Hochschwab massif (redrawn after Bryda 2001). Stratigraphy includes up to 2,000-m-thick sequences of platform carbonates and reef, slope and basinal limestones. Main plateau $\left(\sim 83 \mathrm{~km}^{2}\right.$, yellow-dashed boundary) contains a dense fault network, dominated by (N)NE-(S)SW oriented strike-slip faults. c Major springs (located on the $\mathrm{N}$ and $\mathrm{E}$ slope of the plateau) include the Kläffer spring (karstic limestone dominated catchment, yellow-dashed boundary) and the Pfannbauern spring (fractured dolostone dominated catchment, red-dashed boundary). A tracer test (see unpublished report by Bauer in Table 1) demonstrated the major role of vertical ENE striking strike-slip faults on the drainage pattern of Hochschwab massif. d Discharge curves

catchment of the Pfannbauern spring, had been added to the data set. The Pfannbauern spring, with an elevation of 793 masl, is located on the eastern edge of the Zeller Staritzen area and emerges along a karstified NE-striking fault which is exposed during the spring tapping (Fig. 1b, c). Minimum and maximum mean daily discharge is 245 and 304 1/s, respectively (data from eHyd; Fig. 1d). A discharge ratio of 1.3 calculated from daily means over the year 2011 is indicative of a higher storage capacity within the catchment area and the predominance of fractured over karstified rocks, which is also reflected by hydrological data that show a low variability of physical and chemical parameters as well as low $\mathrm{Ca} / \mathrm{Mg}$ ratios in the spring water (see unpublished report by Stadler and Strobl in Table 1). In addition, water from the Pfannbauern spring has, with 21 years, the highest mean hydrologic residence time of all springs in the area (eHyd 2014). Faults A1 and A2, (Fig. 1b, c) were chosen in order to assess the potential impact of rock type on fault-zone properties and consequently on the regional hydrogeology.

\section{Methods}

The investigation of fault zones integrates field-based structural analysis, fault-rock classification, and fracture-network assessments. Thin-section analysis including standard transmitted light microscopy, electron microscopy (FEI Inspect S) and EDX and porosity/permeability laboratory measurements were performed. The standard damage zone/fault core concept is used, the former being influenced by fault-related fracturing without the formation of new rock types, the latter containing newly formed fault rocks.

\section{Fault-rock classification}

While the initial classification of fault rocks during field work was based on a qualitative, non-genetic, textural scheme (e.g. Sibson 1977, 1986), later in-depth analysis allowed the 


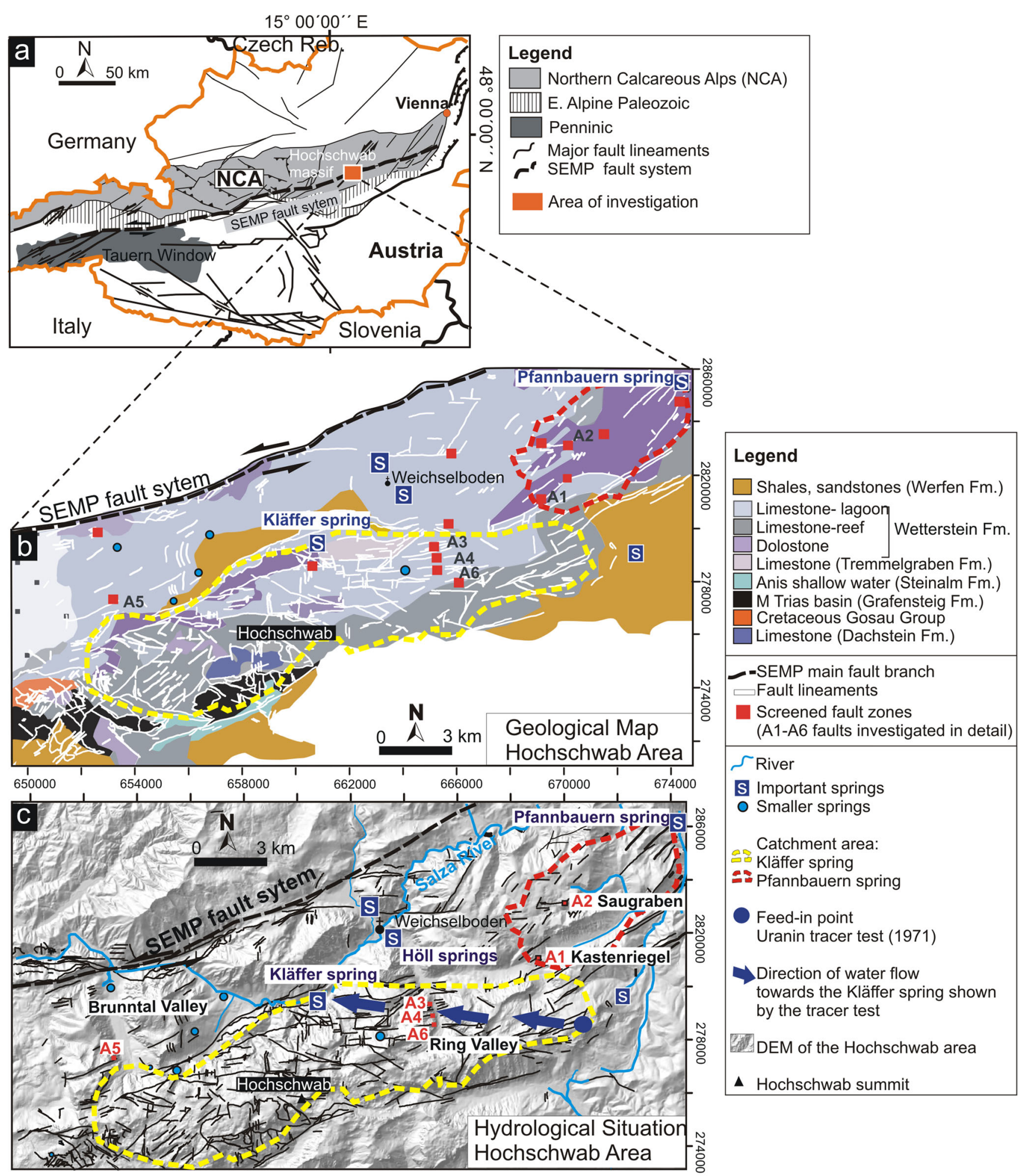

\section{d Discharge Curves}

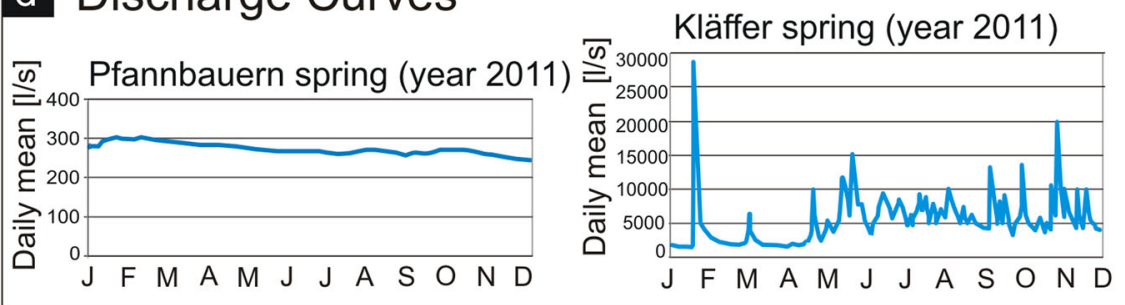

Kläffer spring

mean discharge (1995-2006)

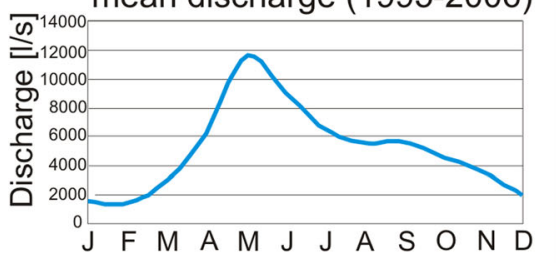


introduction of a reference to genetic processes (e.g. Billi 2010; Woodcock and Mort 2008).

A basic fault-rock differentiation of brecciated rock (0$10 \%$ matrix) and cataclastic rocks (10-100 \% matrix) was used. Cataclastic fault rocks type 1 (Fig. 2a) are grainsupported fault rocks with angular host-rock fragments in point contact and contain $<20 \%$ fine-grained matrix. Type 2 cataclastic fault rocks (Fig. 2b) are characterized by (1) higher contents of fine-grained matrix (approximately $>20 \%$ matrix) and (2) reduced grain sizes.

Dilation breccias (Fig. 2c) show a persistent fragmentation of initially intact host rock, contain $0-10 \%$ matrix and/or cement, and lack evidence of relative displacement, shearing or rotation of fragments. Dissolution-precipitation (DP) breccias (Fig. 2d) contain cm-scale host-rock fragments within a pervasive network of clay-rich, reddish stylolites accompanied by a network of calcite-cemented veins.

\section{Fracture assessment}

Multiple scan lines were used to detect fracture sets and to measure their average spacing, with scan lines perpendicular to each fracture set. The fracture aperture is not included in the analysis since weathering of fractured rock surfaces inhibits their meaningful quantification in the field.

Measurements of mean fracture spacing allow for a volumetric fracture count. The three-dimensional (3D) fracture intensity $\left(P_{32}\right)$ is thereby quantitatively expressed in $\mathrm{m}^{2}$ of joint surfaces per $\mathrm{m}^{3}$ of rock (Dershowitz and Herda 1992).
$P_{32}$ is regarded as the best fracture-intensity measure for systems consisting of a large number of fractures.

Based upon fracture measurements, an empirical classification scheme of fractured rocks was established that allowed classifying and differentiating individual compartments of the damage zones.

Four classes of fractured rock were used (Fig. 2e-h) with individual classes being based on (1) joint set number, (2) average distance of sub-parallel joints, and (3) the block size of joint-delimited blocks. Fracture class 1 (FC 1) refers to very little fractured host rock with $P_{32}<20 \mathrm{~m}^{2} / \mathrm{m}^{3}$, fracture class 2 (FC 2) has $P_{32}$ values ranging from $20-60 \mathrm{~m}^{2} / \mathrm{m}^{3}$, fracture class 3 (FC 3 ) has $P_{32}$ values ranging from $60-200 \mathrm{~m}^{2} / \mathrm{m}^{3}$ and fracture class 4 (FC 4) has $P_{32}$ values $>200 \mathrm{~m}^{2} / \mathrm{m}^{3}$. For a detailed list of $P_{32}$ measurements (see Figure $\mathrm{S} 1$ of the electronic supplementary material (ESM).

\section{Porosity/permeability measurements}

Porosity and permeability measurements were done on 140 samples of fault rocks and fractured host rock. A standard industry procedure (Austrian Standards 1999) was used to determine total effective (matrix and fracture) porosity of sampled rocks. Sample size was selected to cover representative volumes of fractured rocks, depending on the average fracture spacing (up to 2,000 $\mathrm{cm}^{3}$ ). Samples were dried in two steps (48 h in total) at $105^{\circ} \mathrm{C}$ in a laboratory type drying cabinet until mass was constant-mass of dried samples $\left(m_{\mathrm{d}}\right)$. Samples were then put into a water quench. The water column
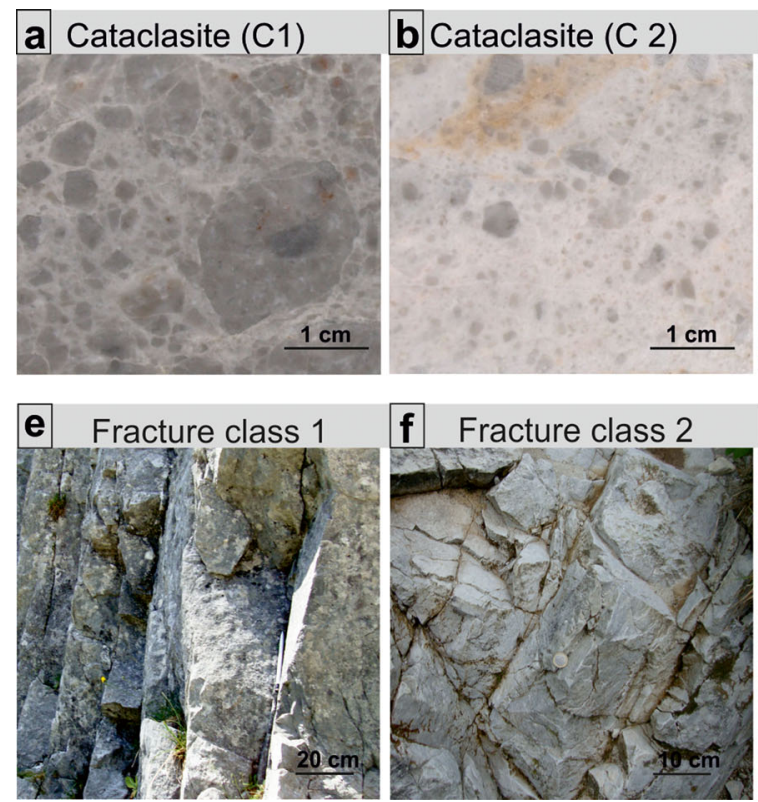

Fig. 2 Rock classification. a-b Cataclasites type $1(C 1)$ and type $2(C 2)$ are differentiated according to grain size and matrix content $(\mathrm{C} 1<20 \%$ matrix, $\mathrm{C} 2>20 \%$ matrix). c Dilation breccias contain high volumes of cal cements separating jigsaw-puzzled fragments of the host rock. d Dissolution-precipitation $(D P)$ breccias contain interconnected clay
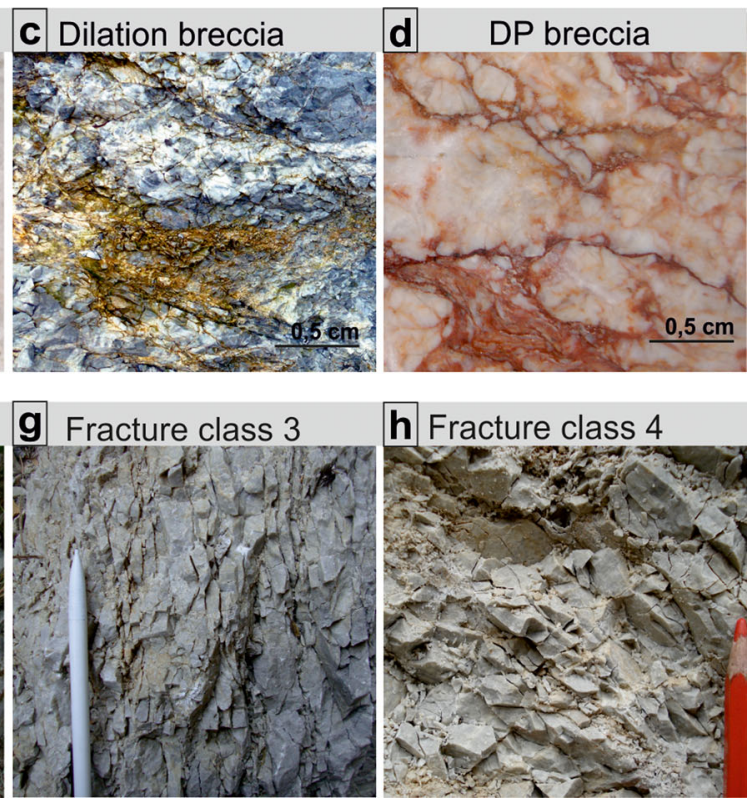

seams and cal cemented veins. e-h Fracture classes 1-4, which differentiate weakly fractured rock (FC 1), moderately fractured rock (FC 2), intensely fractured rock (FC 3 ) and very intensely fractured rock (FC 4) 
was initially chosen at half the sample height so that saturation of samples could be established. Afterwards, samples were completely covered with water (at least $3 \mathrm{~cm}$ cover) for two times $24 \mathrm{~h}$ to ensure full saturation. Wet sample masses were weighted under hydrostatic uplift $\left(m_{\mathrm{h}}\right)$ and in air $\left(m_{\mathrm{s}}\right)$.

$$
\begin{gathered}
\text { Raw density }\left[\mathrm{kg} / \mathrm{m}^{3}\right]: \\
\rho_{\mathrm{b}}=\left(m_{\mathrm{d}} \times \rho_{\mathrm{rh}}\right) /\left(m_{\mathrm{s}}-m_{\mathrm{h}}\right) \\
\text { Total porosity }[\%]: \\
p_{\mathrm{o}}=\left(m_{\mathrm{s}}-m_{\mathrm{d}}\right) /\left(m_{\mathrm{s}}-m_{\mathrm{h}}\right) \times 100
\end{gathered}
$$

The uncertainties of this measuring technique were evaluated by repeated measurements of selected rocks showing errors are within $0.1 \%$ of total porosity, which is considered useful, because it allows measuring porosities of samples large enough to contain a representative number of fractures. This approach is favored over plug measurements which are limited to samples of few centimeters in diameter, where fractures with spacing of a few centimeters or more are not included or completely underrepresented.

$\mathrm{N}_{2}$ porosity and permeability of plug sized samples -1.5 in $(3.81 \mathrm{~cm})$ diameter, $0.72-3$ in $(1.8-7.62 \mathrm{~cm})$ length-were measured using the Coreval Poro 700. Measurements were done using the lowest confining pressure (13.79 bar).

\section{Fault-zone architecture and fault rock content}

\section{Fault zones in dolostone}

Small, low displacement $(<10 \mathrm{~m})$ faults in dolostone are represented by fault A1 (locality Kastenriegel). It is a NE-SW striking strike-slip fault with a total width of $8 \mathrm{~m}$ across the strike (Fig. 3a). The fault contains numerous parallel continuous strands of type 1 cataclastic rock (thickness of $0.5-5 \mathrm{~cm}$, see Fig. 3b, c) surrounded by a 1-m-wide zone of very intensely fractured host rock (FC 4; Fig. 3b). Fault rocks are accompanied by steeply dipping striated slickensides and cloudy distributed volumes of cemented dilation breccias. Open voids within dilation breccias indicate localized hydro fracturing, and idiomorphic crystals show that cements grew within open voids (Fig. 3d). Evidence for fluid-induced fracturing comes also from tension gashes with fibrous calcite. Besides faultparallel tension gashes and dilation breccias, the damage zone is characterized by networks of interconnected, partially cemented fractures. Fracture densities increase from $P_{32}$ values of $25 \mathrm{~m}^{2} / \mathrm{m}^{3}$ (outer damage zone) to $200 \mathrm{~m}^{2} / \mathrm{m}^{3}$ next to fault rocks (Fig. 3b, f). This increase comes from a reduced fracture spacing of all fracture sets and a predominance of fractures orientated sub-parallel to the master fault (lengths of about 1-2 m). Fracture arrays further out include steeply dipping, conjugated N-striking fractures, as well as steeply dipping $\mathrm{NE}-\mathrm{SW}$ fractures and conjugated NW-striking fractures. For the porosity distribution of fractured rock and fault rocks see Fig. 3e and section 'Lithological and hydrogeological characterization of carbonate protolith, fractured rock and fault rock'.

The fault A2 (locality Saugraben) extends for at least $70 \mathrm{~m}$ across strike containing significantly higher volumes of fault rocks and more intensely fractured rocks than fault $\mathrm{A} 1$. The fault strikes (E)NE and separates limestone (SE) from dolostone (NW); no master fault is exposed but is possibly located at the lithological contact between limestone and dolostone. Characteristic features are the absence of thick continuous fault rock in dolostone and a strong asymmetry of the damage zone depending on host-rock lithology.

Within the dolostone, alternating volumes of very intensely fractured rock (FC 4), calcite-cemented dilation breccias and numerous sub-parallel shear zones with strands of cataclastic fault rocks show broadly distributed deformation $\mathrm{N}$ of the master fault (Fig. 4a). Dilation breccias and cataclasites are concentrated in two 2-3-m-wide fault-parallel volumes (zones a1 and a2 in Fig. 4a). Cataclastic fault rocks of type 1 and 2 within these volumes are a few $\mathrm{mm}$ to $5 \mathrm{~cm}$ thick and bounded by small-scaled striated fault planes ( $<10 \mathrm{~m}$ length). At least 6 cataclastic strands occur, which are typically embedded in FC 4 dolostone or in dilation breccias. No single principal slip zone is observed in the dolostone but deformation is distributed over several small localized shear zones, which partially link up to an anastomosing network (Fig. 4a). Dilation breccias (zone a2 in Fig. 4a) develop out of intact host rock which is cut by numerous cemented tension gashes, which finally connect to form fully disintegrated cement-supported breccias.

Large parts of the dolostone damage zone are intensely fractured (FC 3 and FC 4). FC $4\left(P_{32}>>200 \mathrm{~m}^{2} / \mathrm{m}^{3}\right)$ rocks are completely cohesion-less (uncemented) with a fracture spacing of $<2 \mathrm{~cm}$. Rock lithons show no evidence for displacement or shearing, fractures are extensional, pervasively interconnected and not cemented (zones a3 and a4 in Fig. 4a). FC 3 rocks have $P_{32}$ values of 132 and $159 \mathrm{~m}^{2} / \mathrm{m}^{3}$ (Fig. $4 \mathrm{c}$ ). FC 2 rocks show a maximum of fractures oriented parallel to the strike of the fault (Fig. 4b). For porosity distribution of fractured rock and fault rock see (Fig. 4d) and section 'Lithological and hydrogeological characterization of carbonate protolith, fractured rock and fault rock'.

Limestone in the southern damage zone contains fault-parallel, NE-striking fault planes with sub-horizontal lineations and sinistral shear sense. Fracture intensity is significantly lower than in the dolostone $\left(P_{32}\right.$ value $\left.29 \mathrm{~m}^{2} / \mathrm{m}^{3}\right)$. In general, about two thirds of the 70-m-wide fault zone consist of FC 3 and FC 4 host rock (zones a3 and a4 in Fig. 4a).

\section{Fault zones in limestone}

Fault A3 (location Ring Valley) has a distinct master fault with striated slickensides and a very thin zone of 

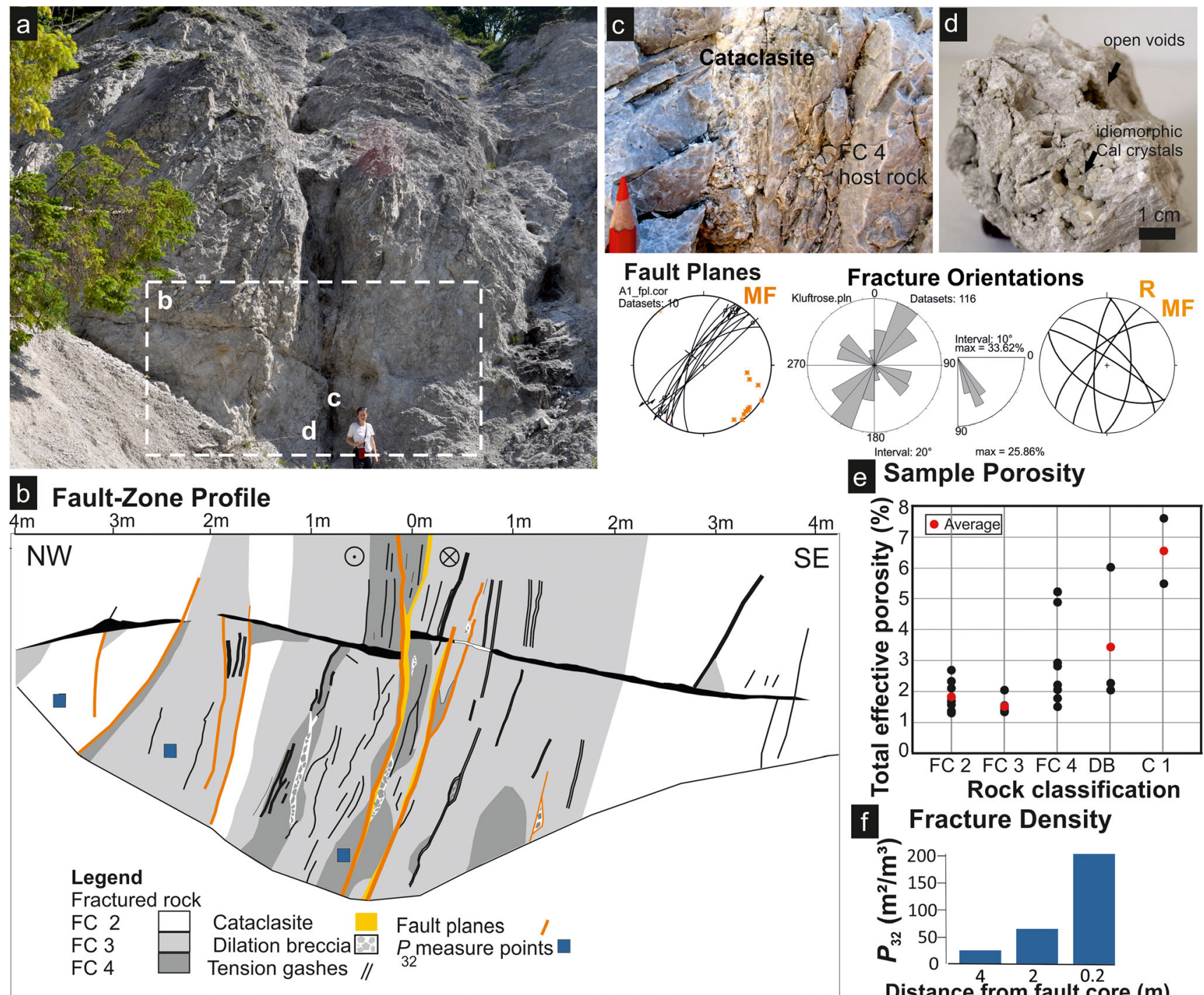

e Sample Porosity

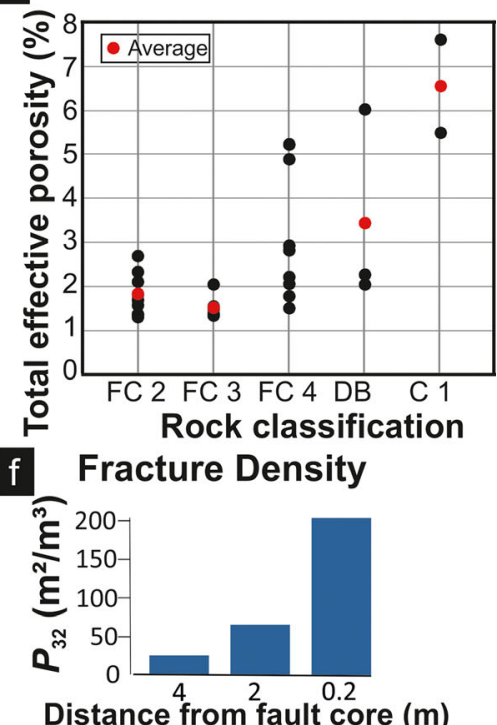

Fig. 3 a Low-displacement $(<10 \mathrm{~m})$ dolostone fault (A1) contains a multiple-stranded cataclastic fault core with potential incipient karst features found in the upper half of the outcrop. In the white-dashed box, $b, c$ and $d$ refer to the locations of the respective figure parts. b Fault zone profile showing the distribution of fault rocks and variable fracture densities. c Two strands of cataclasites (type $\mathrm{C} 1$ ) are surrounded by zones of FC 4 host rock and cemented dilation breccias. d Dilation

cataclastic fault rock varying from a few $\mathrm{mm}$ to $20 \mathrm{~cm}$ (Fig. 5a). The cataclastic zone contains cohesive, cemented type 1 cataclastic fault rock, neither breccias nor highly fractured rocks are part of the fault core (Fig. 5c). The damage zone is characterized by low fracture densities (Fig. $5 \mathrm{~d}$, e) with a maximum $P_{32}$ value of $39 \mathrm{~m}^{2} / \mathrm{m}^{3}$ (FC 2) even adjacent to the master fault. The rock volume is dominated by a fracture set striking parallel to the master fault and synthetic Riedel shears. Fractures are a few meters long and spaced at average distances of $5 \mathrm{~cm}$ (Fig. $5 \mathrm{c}$ ). Short subhorizontal fractures abut against these fractures. Further NW of the fault core, Riedel shear parallel fractures are much less breccias contain macroscopic open voids and pores. e Total effective porosities, ranging from 1.5 to $3 \%$ average for fractured rocks. Faultrock types showing variable porosities due to different degrees of cementation. f Fracture densities, increasing close to cataclastic strands and dilation breccias (average porosities of fractured rock remain $<3 \%$ ). $R$ Riedel parallel fractures; $M F$ master fault

abundant and total fracture density drops to $19 \mathrm{~m}^{2} / \mathrm{m}^{3}$ at about $20 \mathrm{~m}$ from the fault core. The damage zone south of the master fault does not have a fracture network of synthetic and antithetic Riedel shears and low $P_{32}$ values of $15 \mathrm{~m}^{2} / \mathrm{m}^{3}$ (FC 1). Fractured rock and cataclastic fault rocks have porosities $<2 \%$. Porosities of the fractured rock are underestimated, as high fracture spacing $(>10 \mathrm{~cm})$ within FC 2 cannot be adequately sampled (Fig. 5c). The fault zone shows karstification along the fault core as documented by relicts of eroded cave sinters (Fig. 5b) oriented parallel to the master fault. Within the damage zone, no karstification features have been observed. 


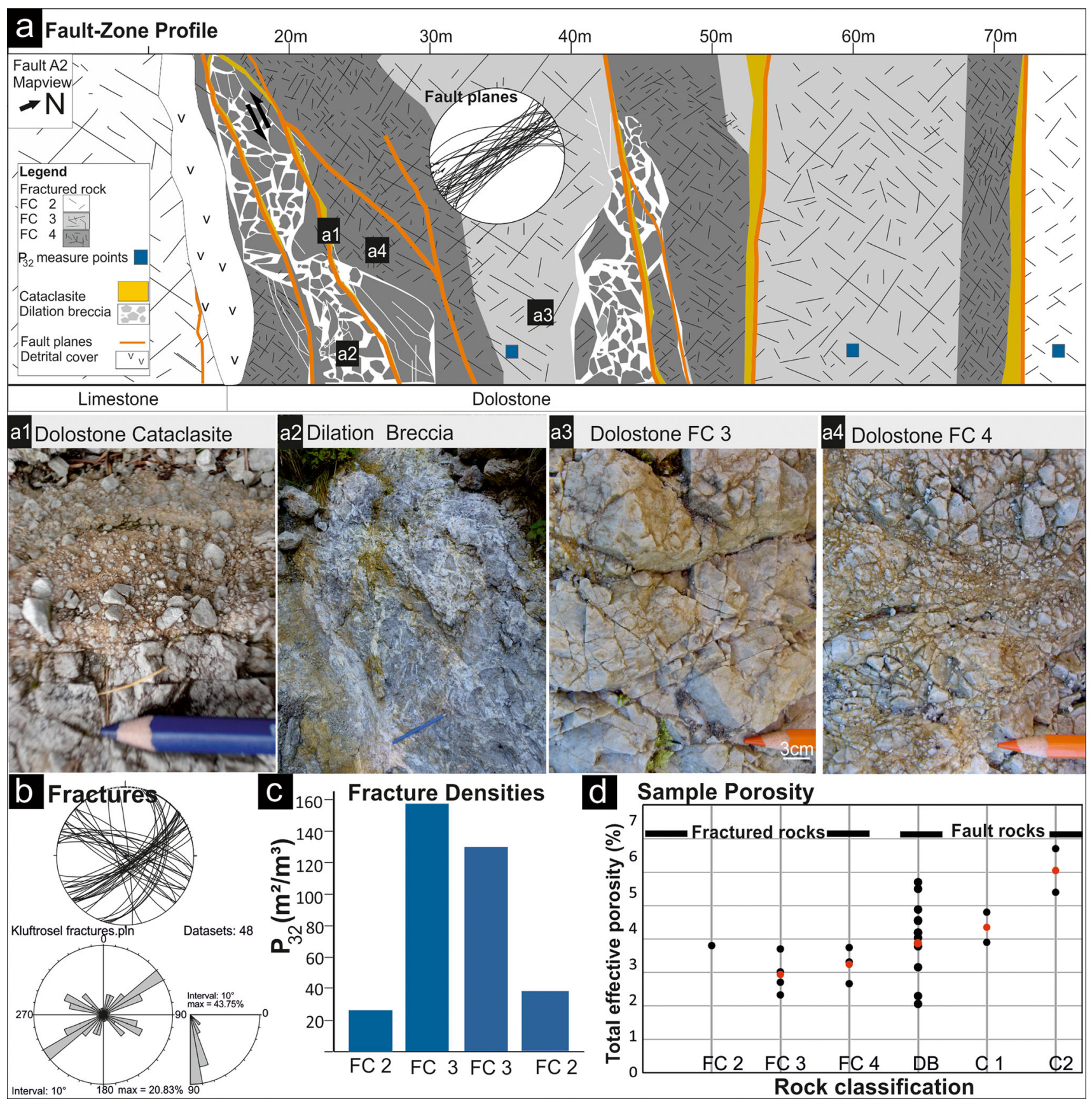

Fig. 4 a The higher-displacement dolostone fault A2 has no definite fault core but several sub-parallel, anastomosing, cataclastic shear zones with (al) cataclasites type (C1) and (C2), max. $10 \mathrm{~cm}$ thick, and (a2) two several-meters-thick fault-parallel zones of cement-supported dilation breccias. Additionally, dolostone classified as (a3) FC 3 and (a4) FC 4, which is pervasively fractured (high densities of uncemented, interconnected tensile micro-fractures), makes up about more than two thirds of the fault zone volume. b The limestone contains significantly lower fracture densities with a maximum of fractures oriented parallel to the fault strike. c Fracture densities measured over the fault. Note: No fracture density measurements of FC 4 rock could be done due to the high fracture densities. d Total effective porosities, ranging from 2.5 to $4 \%$ for fractured rocks. Dilation breccias and cataclastic rocks reveal porosities $>4 \%$ average. Uncemented FC 4 rocks could not be adequately sampled
Fault A4 (location Ring Valley) comprises an 2-m-thick continuous fault core with large E-striking sub-vertical principal slip planes and sub-horizontal sinistral lineations (Fig. 6a). The fault core is composed of a continuous strand of cataclastic rock and brecciated as well as intensely fractured host rock (FC 4) and breccia. FC 4 rock forms lens-shaped compartments delimited by fault planes (Fig. 6c). The cataclastic zone reaches a maximum thickness of $40 \mathrm{~cm}$, 

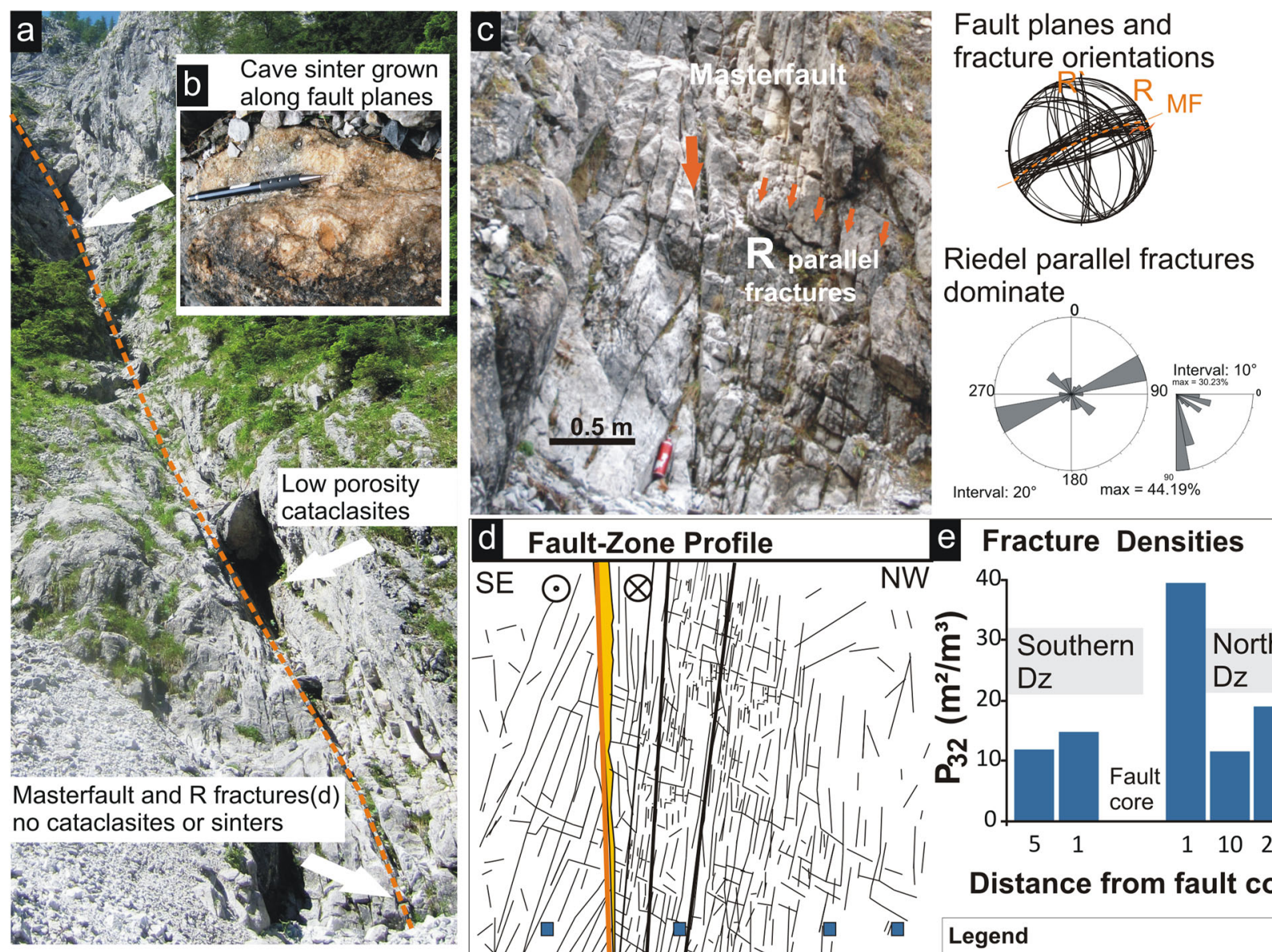

\section{e Fracture Densities}
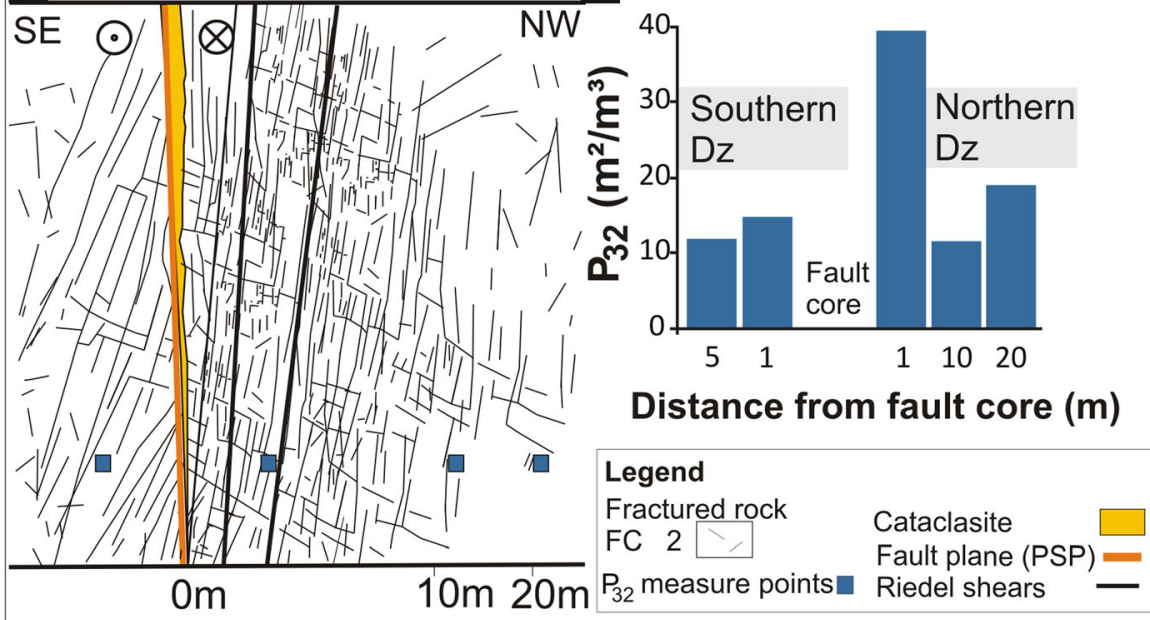

Fig. 5 a Low-displacement limestone fault A3 shows a distinct subvertical master fault with $\mathbf{b}$ karstification documented by relicts of cave sinters within cavities located along the master fault. $\mathbf{c}$ The fault core is marked by a thin discontinuous zone of $\mathrm{cm}$-thick cemented cataclasite type $1(\mathrm{C} 1)$. Numerous subparallel Riedel shears cut the host rock within

containing a cohesive, cemented type 2 cataclasite marking the principal slip plane. FC 4 host rock incorporated into the fault core is completely disintegrated (minor cemented) with low contents of fine-grained matrix (Fig. 6b). A dolomitic dilation breccia with cloudy distribution is found at the northern boundary of the fault core, indicating either a dolomitization along the fault core or primary impurities in the limestone host rock.

Limestone host rock in the damage zone contains largescale synthetic and antithetic Riedel shears. The southern damage zone contains a more than 20-m-wide array of major synthetic Riedel shears with convex-up shape that branch from the fault core (Fig. 6a). Fracture arrays cut by largescale Riedel shears include N-striking sub vertical fractures, sub-horizontal W-dipping fractures, and conjugated SW- and NE-dipping fractures. The distribution of fracture densities across the damage zone in a profile perpendicular to the fault the damage zone. $\mathbf{d}$ The damage zone shows systematic fractures in Riedel shear orientation (anisotropic fracture pattern), but contains $\mathbf{e}$ exclusively low fracture densities $(F C 2) . R$ Riedel parallel fractures; $P S P$ principal slip plane; $M F$ master fault

shows a slight increase of $P_{32}$ values from the outer damage zone by a factor of 2 towards the fault core in an approximately 10-m-wide zone (Fig. 6f). In general, fracture densities are asymmetrically distributed over the damage zone. Porosities increase from FC 2 to FC 4 rock and are reduced within the cataclastic fault core (see Fig. 6e and section 'Lithological and hydrogeological characterization of carbonate protolith, fractured rock and fault rock').

The fault zone is karstified along the fault core. Numerous relicts of karstic pipes are located along anastomosing, large-scale fault planes (Fig. 6c). Cataclasite samples taken next to each other show a porosity of 3.5 and $6.5 \%$, respectively. The elevated porosity is due to inhomogeneously distributed voids formed by secondary dissolution of fine-grained cataclastic matrix (see section 'Lithological and hydrogeological characterization of carbonate protolith, fractured rock and fault rock'). 


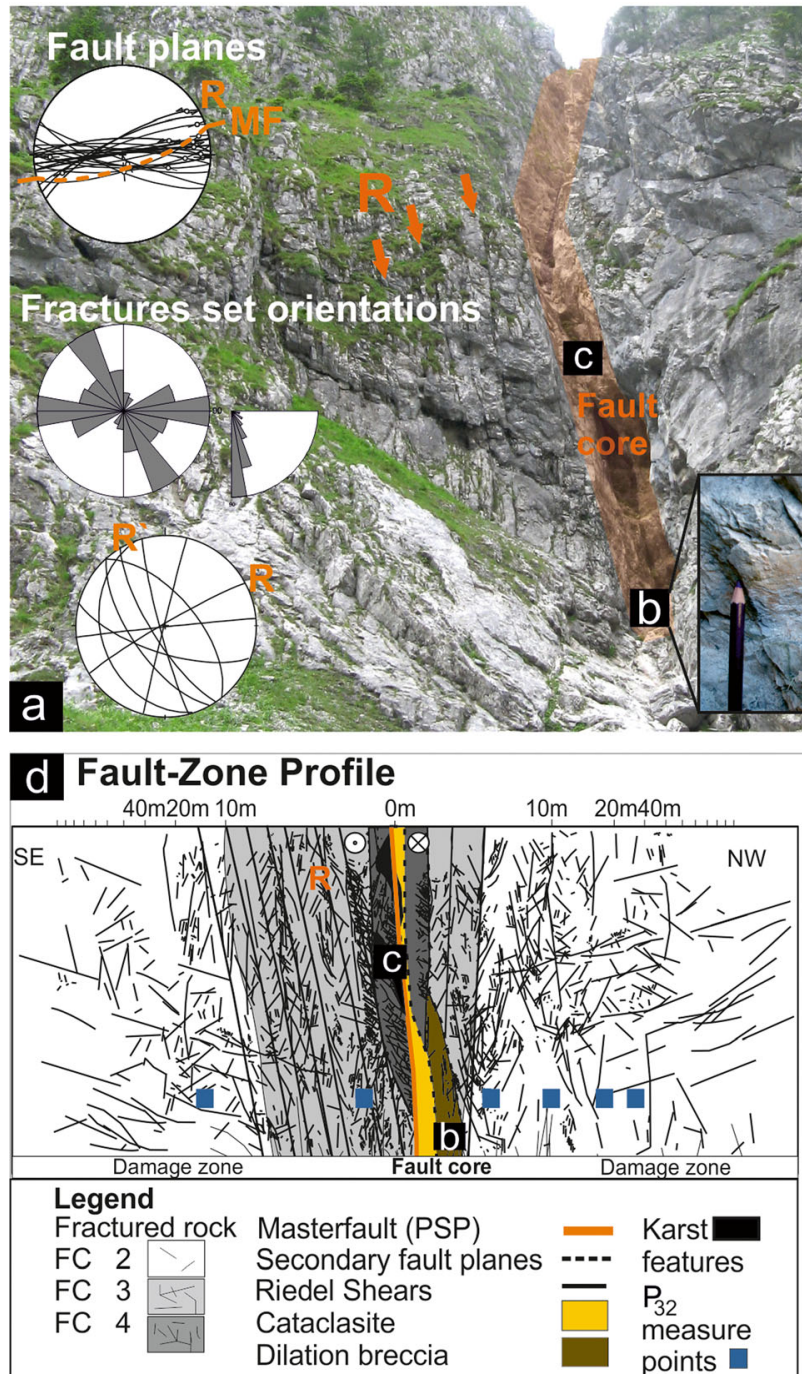

Fig. 6 a Limestone fault A4 (80-m-wide strike), which contains a 2-mthick fault core with several slicken-sided fault planes and a continuous cataclastic strand (max. 20-cm thickness, master fault, $M F$ ). The host rock outside the fault core is cut by major Riedel-shears $(R)$ (more abundant in southern DZ). b The fault core contains cataclastic fault rocks type 1 and $2(\mathrm{C} 1,2)$ and intensely fractured and brecciated rock delimited by distinct fault planes. c Karstification features bound to the fault core, along interconnected fault planes encompassing lens-shaped (white-dashed area) compartments of very intensely fractured host rock and breccias ( $\mathrm{cm}$ to

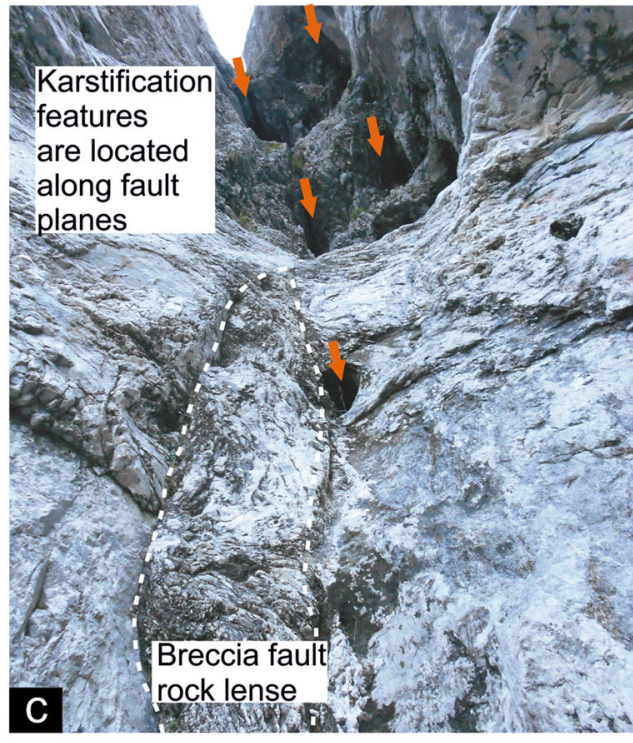

e Sample Porosity

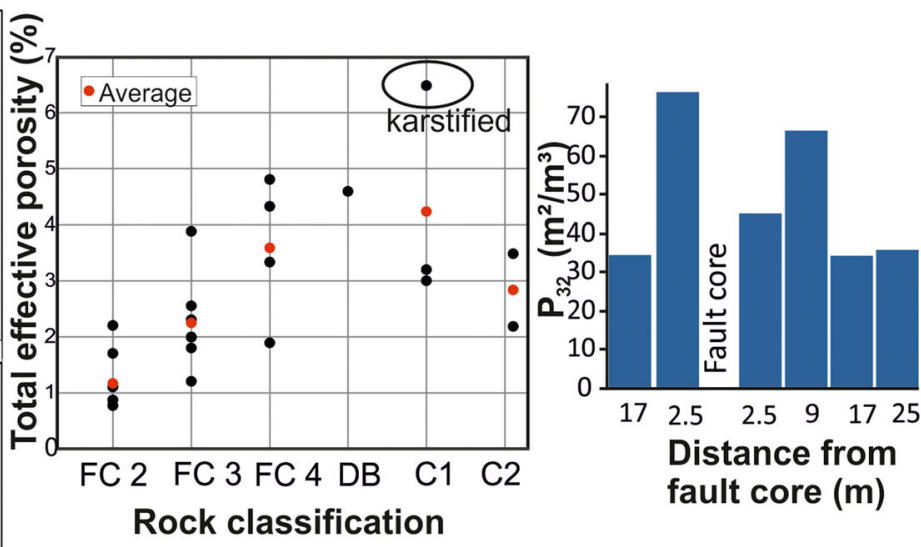

meters). d Fault-zone profile showing the distribution and geometric relations of fault rocks and fractured rocks throughout the fault core and damage zone. Letters $b$ and $c$ refer to the locations of the respective figure parts. e Fractured rock shows an increase of effective porosities by a factor 3. Cataclasites have average porosities of $3 \%(6.5 \%$ indicating karstification). f Damage-zone fracture densities $<40 \mathrm{~m}^{2} / \mathrm{m}^{3}$ are remote from the fault core and up to $76 \mathrm{~m}^{2} / \mathrm{m}^{3}$ close to the fault core. $R$ Riedel parallel fractures; PSP principal slip plane

fractured rock assemblages underwent pronounced deformation with respect to the FC3 host rock and are therefore described as part of the fault core, similar to fault A4 (Fig. 7c). On both sides of the cataclasites, an at least 4-m-thick zone of extremely fractured rock is laterally continuous, unlike fault A4 where similar fractured rocks are restricted to discontinuous lenses and isolated rock volumes. Small volumes of dilation breccias appear within FC 4 rocks and are characterized by abundant open voids (porosity $>5 \%$, Fig. $7 \mathrm{~h}$ ) between slightly displaced angular host-rock fragments.

The damage zone adjacent to the fault core with its FC4 rocks and cataclasites is characterized by fracture densities of slickensided fault planes (Fig. 7c). These brecciated and 

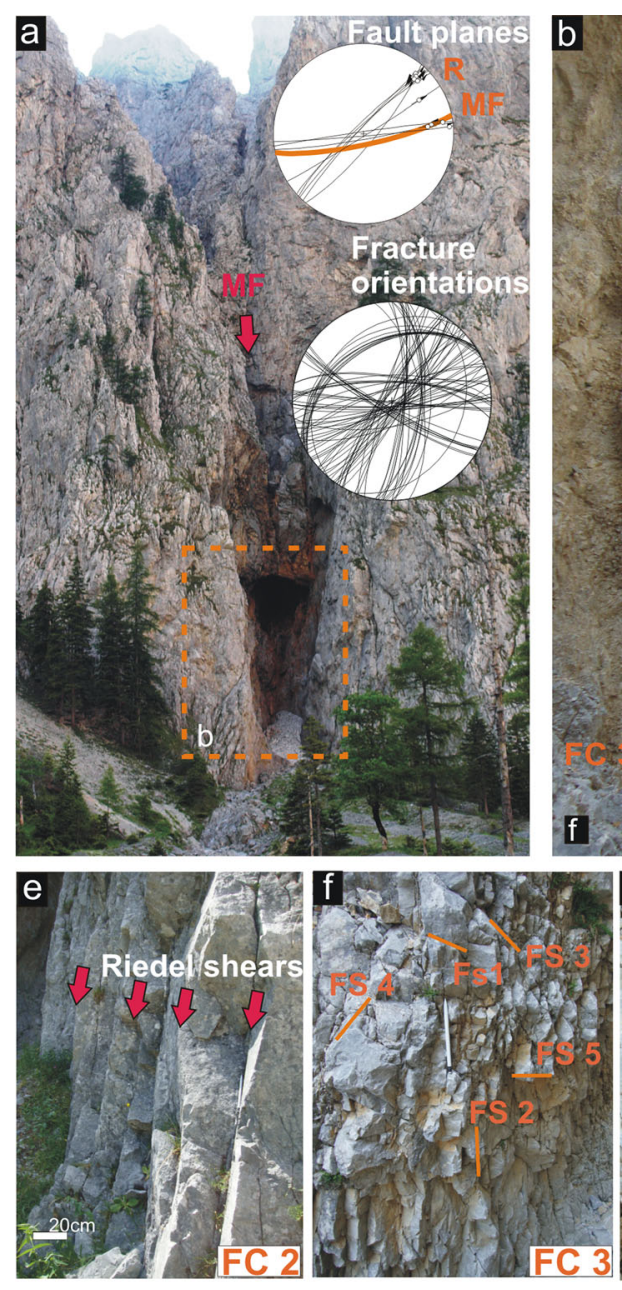

Fig. 7 a-b Limestone fault A6 with strongly karstified fault core of several meters thickness. A relict karst cave is located along the master fault $(M F)$, where cataclasites, breccias and fractured rocks have been completely removed. Below the karst cave, the fault core is excellently exposed with a laterally continuous zone of cataclasites (C 1, 2; up to several decimeters thick) and there is a complex mélange of secondary fault planes (shown in c), FC 4 rocks and brecciated rocks. Cataclasites and breccias are cemented. d Breccias showing karstification. e- $\mathbf{g}$

about $80 \mathrm{~m}^{2} / \mathrm{m}^{3}$ (FC 3; Fig. 7f). Fracture arrays appear isotropic although Riedel-parallel fractures are more pervasive in some areas. Some major fault planes, striking parallel to the master fault, cut the FC 3 host rock and are accompanied by 10-cm-thick strands of FC 4 host rock (Fig. $7 \mathrm{~g}$ ). The damage zone remote from the fault core is classified as FC 2 (Fig. 7e). Large-scale synthetic Riedel shears only occur in a narrow zone $\mathrm{N}$ of the fault where fracture densities are significantly lower than in the damage zone to the $\mathrm{S}$. Low fracture densities with $P_{32}$ values around $20 \mathrm{~m}^{2} / \mathrm{m}^{3}$ characterize these outer parts of the damage zone that extend about $70 \mathrm{~m}$ to the $\mathrm{N}$ and S. Porosities of fractured rock (Fig. $7 \mathrm{~h}$ ) are $4 \%$ for FC 4 and $<2 \%$ for FC 3 (for discussion see section 'Lithological and hydrogeological characterization of carbonate protolith, fractured rock and fault rock').
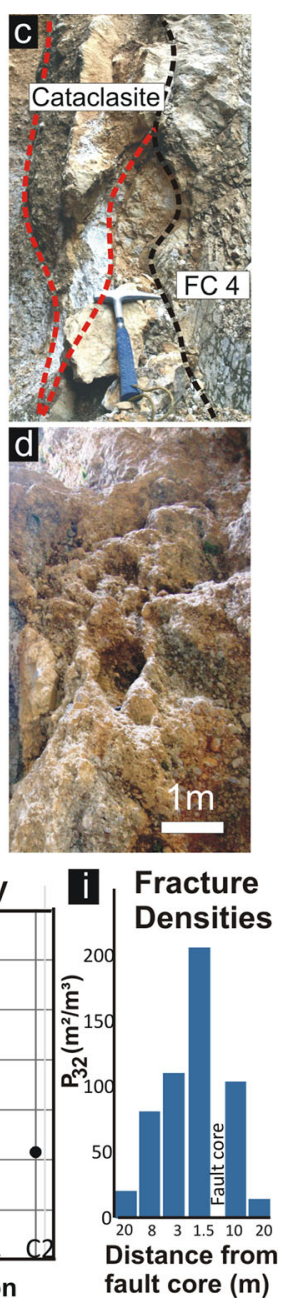

Fracture densities showing significant increase towards the fault core. Remote from the fault core, the host rock is characterized by FC 2 (e). f FC 3 host rock closer to the fault core, showing up to five inter-connected fracture sets $(F C 1-5$, spacing $<7 \mathrm{~cm})$. g FC 4 host rock, which shows pervasive, interconnected fractures, with spacing $<2 \mathrm{~cm}$. h Porosities are highest for fractured (FC 4) and brecciated rocks (about $5 \%$ ); cataclasites show reduced porosities. i $P_{32}$ values increase by a factor 10 from FC 2 rock to FC 4. $R$ Riedel parallel fractures

The fault contains relicts of an ancient karst cave with a diameter of 7-8 m (Fig. 7a, b). The cave profile, due to its keyhole-shape, may indicate initial cave formation under phreatic conditions and a later switch to vadose conditions. In the upper part, the cave formed symmetrically around the master fault. In the accessible part of the fault, below the cave level (Fig. 7b), cataclasites, breccias and FC 4 rocks are exposed in their original context. On the macroscopic scale, only breccias show explicit signs of secondary dissolution (Fig. 7d).

Fault A5 (location Griesgassl Brunntal Valley). Though not in the catchment of the Kläffer spring, this fault has been selected because it belongs to the same deformation phase D3 as the other faults, albeit with a larger displacement. Faultzone architecture and increased thickness of the cataclastic fault core are the consequence of a larger slip displacement. 
The dominant structural elements are ENE-striking, sinistral strike-slip fault planes with (sub)-horizontal lineations. Associated major Riedel shears strike NE with sinistralreverse lineations confirming that A5 forms a major flower structure at a local transpressional fault segment (Fig. 8a). The fault core is made up of a 4-m-wide cataclastic fault rock that is laterally continuous throughout the available outcrop. Grain-size variations within the cataclastic rocks are observed

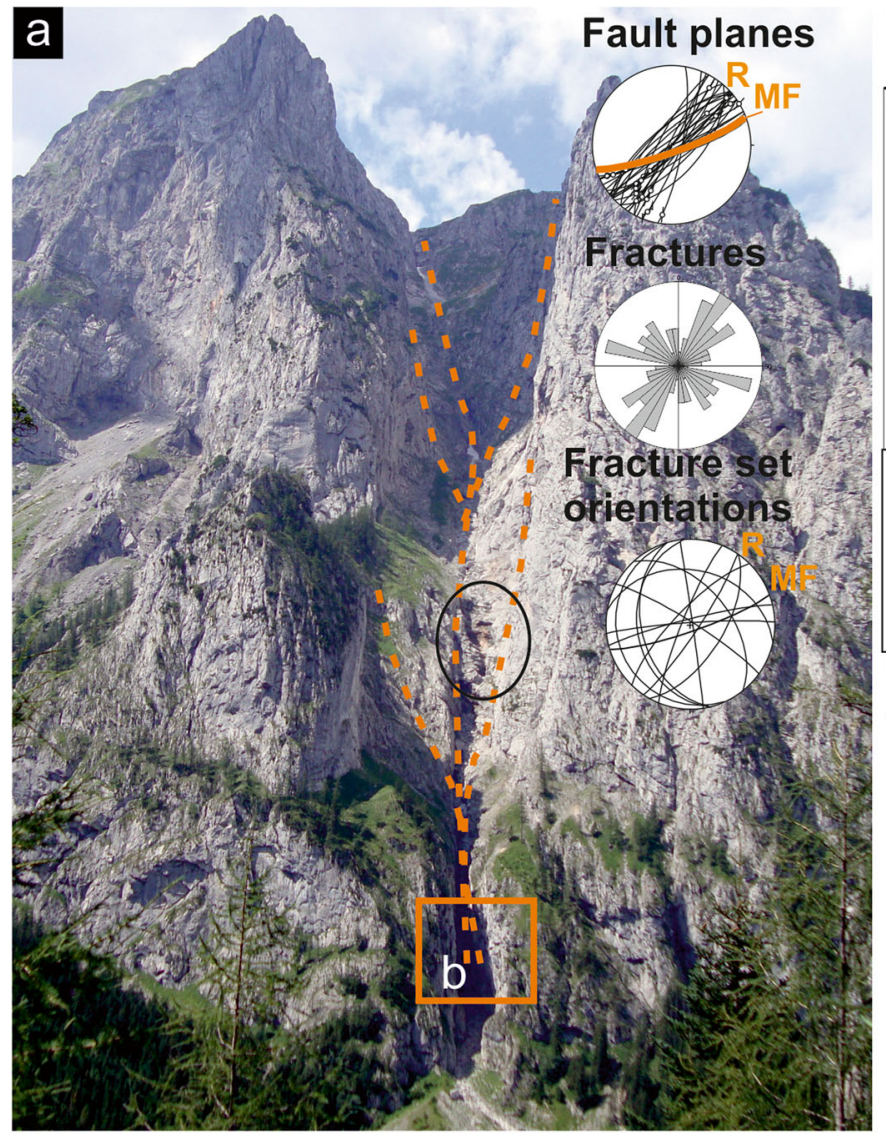

but the bulk of the cataclasite is a very cohesive, cemented type 2 cataclasite (porosity $<2 \%$; Fig. 8 f). At the border of the cataclastic fault core, host rock was observed that is pervasively dissected by stylolithic fault planes, and in some areas clayrich breccias accompanying secondary faults are branching away from the master fault (Fig. 8e). These DP breccias are restricted to some decimeters in thickness and have porosities $<2 \%$.

\section{b Fault-Zone Profile}

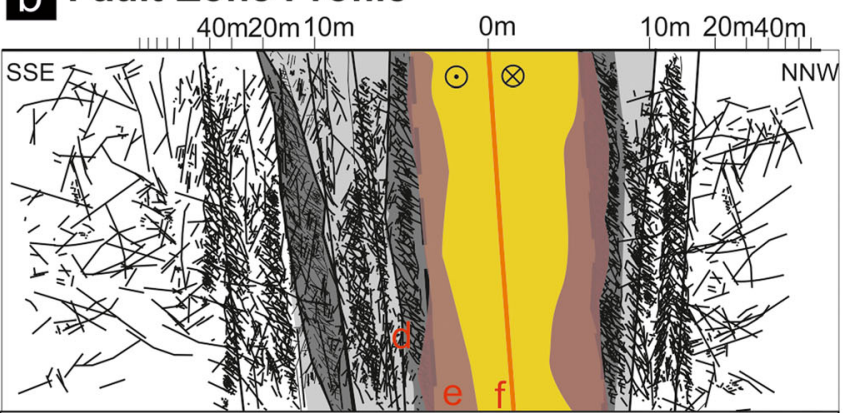

Legend

Fractured rock

FC 2 Masterfault (PSP) Cataclasite

FC 3 世 Secondary fault planes $\quad$--- DP breccia FC 4 Riedel Shears

\section{Sample Porosity}
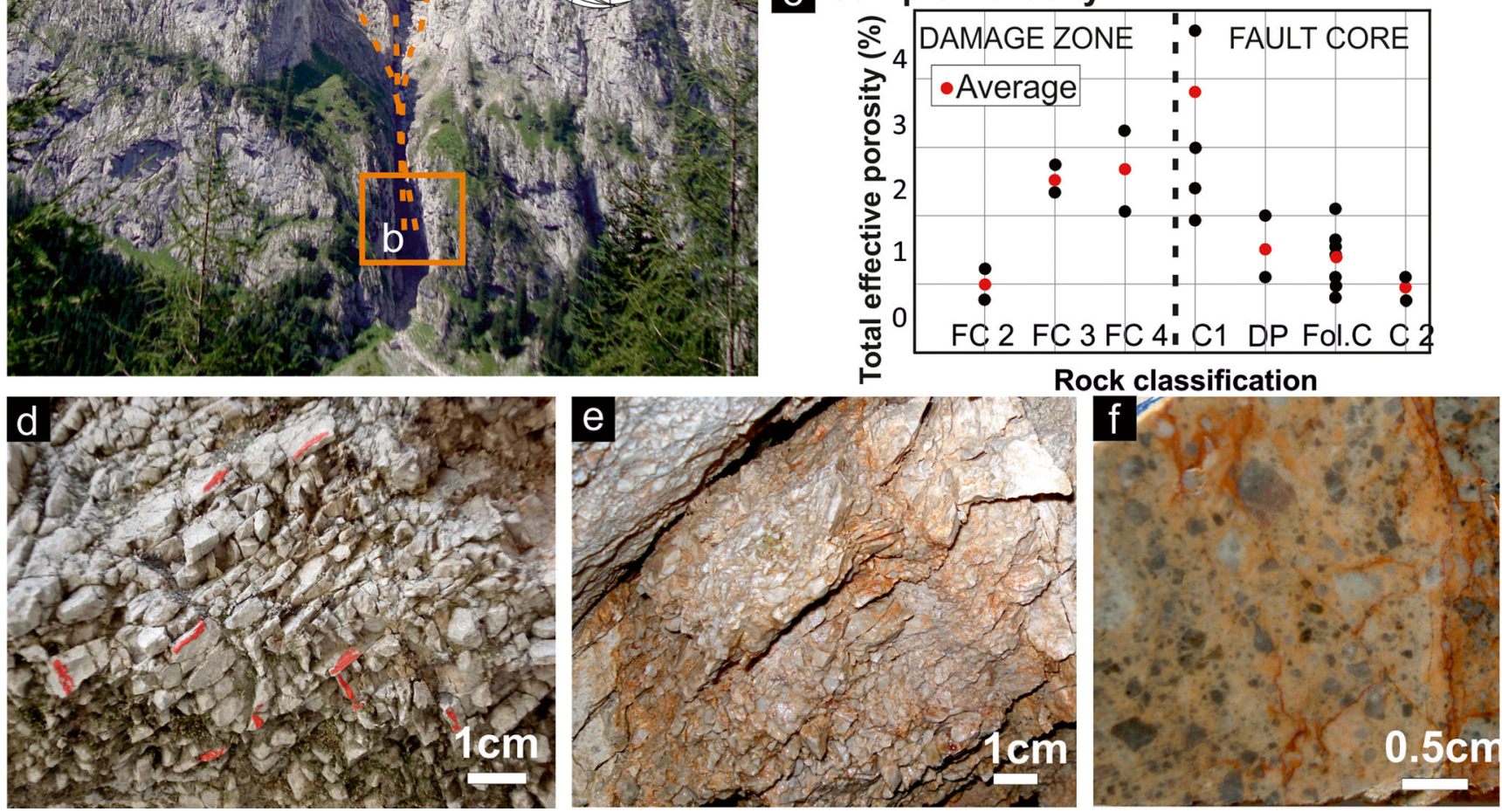

Fig. 8 a Large-scale limestone strike-slip fault A5, showing characteristics of compressive flower structure. There is possible karstification in inaccessible parts of fault (black ellipse). b The accessible part of the fault (orange box in a) contains a continuous 4-mthick cataclastic fault core and large-scale $(>100 \mathrm{~m})$ branching secondary fault planes that cut and/or delimit compartments of brecciated and fractured rock $(F C 3, F C 4)$. c Fault-rock porosities show decrease from type 1 cataclasites $(C 1$; average $3.8 \%)$ to pressure solution breccias $(D P$; $1.6 \%)$ and foliated type 2 cataclasites $(C 2 ; 1 \%)$. d Uncemented FC 4 rock close to the fault core; red marks refer to fracture sets. e-f The fault core, showing zoned build-up, with clay DP breccias along margins (e), followed by cataclasite type 1 and finally cataclasites type 2 in the center (f). $R$ Riedel parallel fractures; $P S P$ principal slip plane; $M F$ master fault 
The damage zone next to the fault core is characterized by large-scale $(>>10 \mathrm{~m})$ synthetic NE-striking slickensided Riedel shears with sub-horizontal lineations. The host rock between the Riedel shears shows high fracture densities (FC 3 or 4; Fig. 8d). $P_{32}$ values vary between 100 and $200 \mathrm{~m}^{2} / \mathrm{m}^{3}$. These volumes of highly fractured host rock are distributed asymmetrically around the fault core. The overall thickness of the fault zone is estimated around $120 \mathrm{~m}$ (Fig. 8b). Unfortunately, not enough measurements could be taken to come up with a detailed profile of fracture densities across the fault. $P_{32}$ values within the outer part of the damage zone are estimated to drop significantly to FC 2 levels; for porosity distribution see Fig. 8c.

The fault A5 shows no karstification of the fault core, only a mechanical break-out of cataclastic fault rocks, and no significant karstification within the damage zone. Only subordinate dissolution features $<1 \mathrm{~m}$ are observed along large-scale secondary fault planes branching from the fault core. Potential relicts of karstification are observed from the inaccessible upper part of the fault (dark ellipse in Fig. 8a)

\section{Lithological and hydrogeological characterization of carbonate protolith, fractured rock and fault rock}

\section{Protolith}

Lithology. Lagoonal Wetterstein dolostone is typically a light grey sucrose dolostone with infrequent relicts of laminated bindstones and dasyclads. Dolostone hosting fault A1 predominantly consists of polymodal dolomites (grain size of 20-50 $\mu \mathrm{m}$ ) with minor microporosity of isolated pores and minor fractures (pore diameters about 5-20 $\mu \mathrm{m})$. Dolostone protolith hosting fault A2 shows a slightly different, polymodal texture of variable dolomite grain sizes (3-50 $\mu \mathrm{m}$; Fig. 9a). Lagoonal Wetterstein limestone (Fig. 9g) is typically a light grey, finegrained wackestone to biosparitic grainstone or rudstone with algal lumps, oncoids, foraminifers, bivalves, gastropods and frequent dasyclads, hosting laminated bindstones with fenestral fabrics.

Porosity and permeability. Wetterstein dolostone (D) and limestone (L) host rock (FC 1) outside fault zones has very low porosities of $1.1 \%$ (D) and $0.9 \%$ (L) (Fig. 10a, b).

\section{Fractured host rock}

Lithology. Fracture class 1 (FC 1) with very low fracture densities $\left(<20 \mathrm{~m}^{2} / \mathrm{m}^{3}\right)$ occurs along low-displacement faults A1 and A3. FC 2 with 2-3 clearly recognizable fracture sets with an average spacing $>10 \mathrm{~cm}\left(20-60 \mathrm{~m}^{2} / \mathrm{m}^{3}\right)$ is found along all fault zones. Fractures are systematic and/or non-systematic but are still highly interconnected. FC 3 rocks are found close to fault cores and contain 3-5 different fracture sets with average fracture spacings of $3-10 \mathrm{~cm}$. Anisotropies within FC 3 rocks are observed where fracture sets in the orientation of syn- and antithetic Riedels are systematic and transect other more subordinate fracture sets. Extremely closely fractured FC 4 contains highly isotropic, systematic and interconnected fracture arrays and is observed closest to fault cores in all faults except for A3 and A4.

Porosity and permeability. Comparing mean porosities of fractured rocks shows that the difference in the mean porosity between $\mathrm{FC} 2,3$ and 4 is $2 \%$ at maximum (Fig. 10a, b) in both limestone and dolostone. Despite this increase of porosity with higher fracture class, even FC 3 and FC 4 rocks are effectively low-porosity rocks. In addition, there is a significant spread of measured porosities within the individual fracture classes, with standard deviations varying from 0.4 (FC 2) to 1.4 (FC 4) which is almost equal to the variation of means of the different classes.

In Fig. 10c, fracture porosities (a subset of the data points in Figs. 10a, b) coming from hand specimens are plotted against $P_{32}$ values coming from field observations. Both the modeled fracture aperture/porosity curves and the chosen boundaries of fracture classes are overlain. Four factors could contribute to the increasing standard deviation of porosities with increasing fracture density and to the fact of having similar porosity measurements for different fracture-density classes observed in Fig. 10a, b. Firstly, being the natural variation of matrix porosity in the protolith, and secondly, each sample of fractured rock will contain not only fractures of a single but of varying apertures. Fractures of seemingly large apertures could be introduced by the sampling process during which fractures are widened mechanically. Thirdly, an increase in intensity of fracturation of a protolith will lead to an increase of fractures of all apertures present in a sample. Thus, to a higher degree, micro-fractures may contribute to porosity. This effect is however restricted to $<1 \%$ due to their small apertures. And fourthly, with increased fracture density, and thus higher initial permeability, the probability of cementation and consequently destruction of pore space increases. Plug permeabilities range from 0.1 to $1.8 \mathrm{mD}$ (Fig. 10d). No plugs of FC 4 dolostones with extremely high densities of uncemented fractures could be drilled.

\section{Dilation breccias}

Lithology. Breccias are typically very variable in terms of volume and spatial distribution around the faults, delimited by non-planar boundaries with more or less cloudy spatial distribution (breccia pockets). Micro-structural investigations show that dolostone faults contain dilation breccias with jigsaw puzzles of angular fragments of host rock (mm 

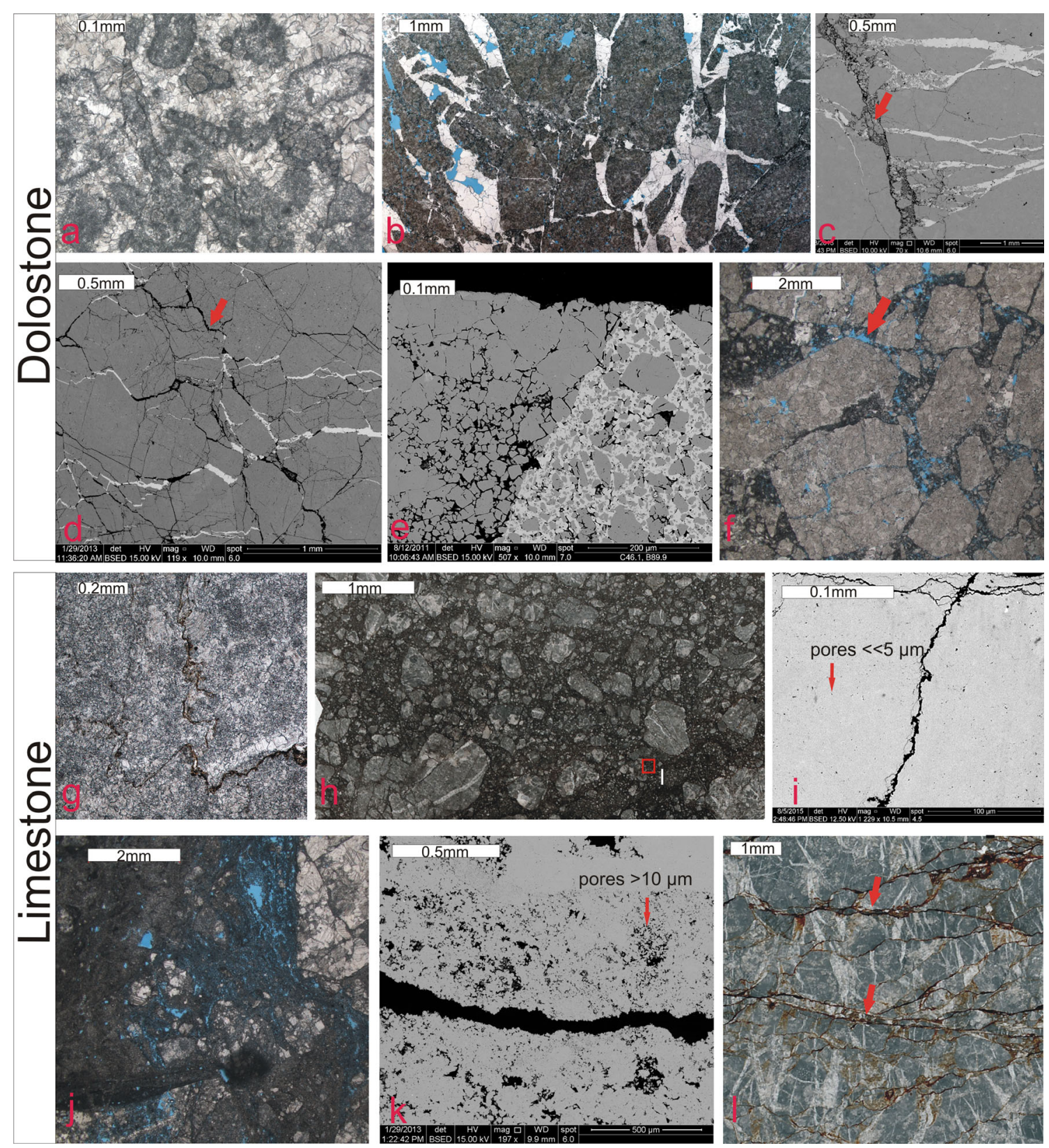

Fig. 9 Dolostone micro structures. a Dolostone protolith (grain size 20 $50 \mu \mathrm{m}$ ), with minor primary porosity. b Dilation breccias (fault A1): jigsaw-puzzled host-rock fragments separated by calcite cement. c Dilation breccias: cemented micro-fractures cut by highly porous, uncemented fracture, filled with fine-grained host-rock material (localized in-situ pulverization). d FC 4 dolostone: high density of uncemented micro-fractures. e Cataclasite type 2: grains $<0.1 \mathrm{~mm}$, containing high amount of matrix porosity. Pores partially sealed by calcite cements. f Cataclasite type 1: angular-shaped fragments and heterogeneously distributed matrix (connected pores $<0.2 \mathrm{~mm}$ ).

to $\mathrm{cm}$ in size) that are separated by a connected and pervasive network of fractures and veins, which are partially filled with either cements and/or minor fine-grained matrix particles (Fig. 9b). Dilation breccias are very heterogeneous when it comes to cementation. They generally lack crack-seal
Limestone micro-structures; blue refers to porosity g Limestone protolith (grain size $<10 \mu \mathrm{m}$ ): low matrix porosity. $\mathbf{h}$ Cataclasite type 2 : rich in fine-grained matrix $(>50 \%)$ and larger $(>0.5 \mathrm{~mm})$ protolith fragments, which have very low porosity (pores $<<5 \mu \mathrm{m}$ ) due to complete cementation or recrystallization of matrix (red boxed area detailed in i). j Cataclasite type 2: dissolution of fine-grained matrix (blue). k Cataclastic matrix (connected pores, diameters of 5-50 $\mu \mathrm{m}$ ) with relatively high porosities (up to $6 \%$ ). I Pressure-solution breccias: high proportion of calcite-cemented veins, pervasive network of claybearing stylolites (brown layers)

structures but show evidence for multi-stage cement growth. Cements precipitated from calcite fluids sealed only part of the porosity. As a result, highly porous portions are next to completely cemented portions, even on a thin-section scale (Fig. 9c). 


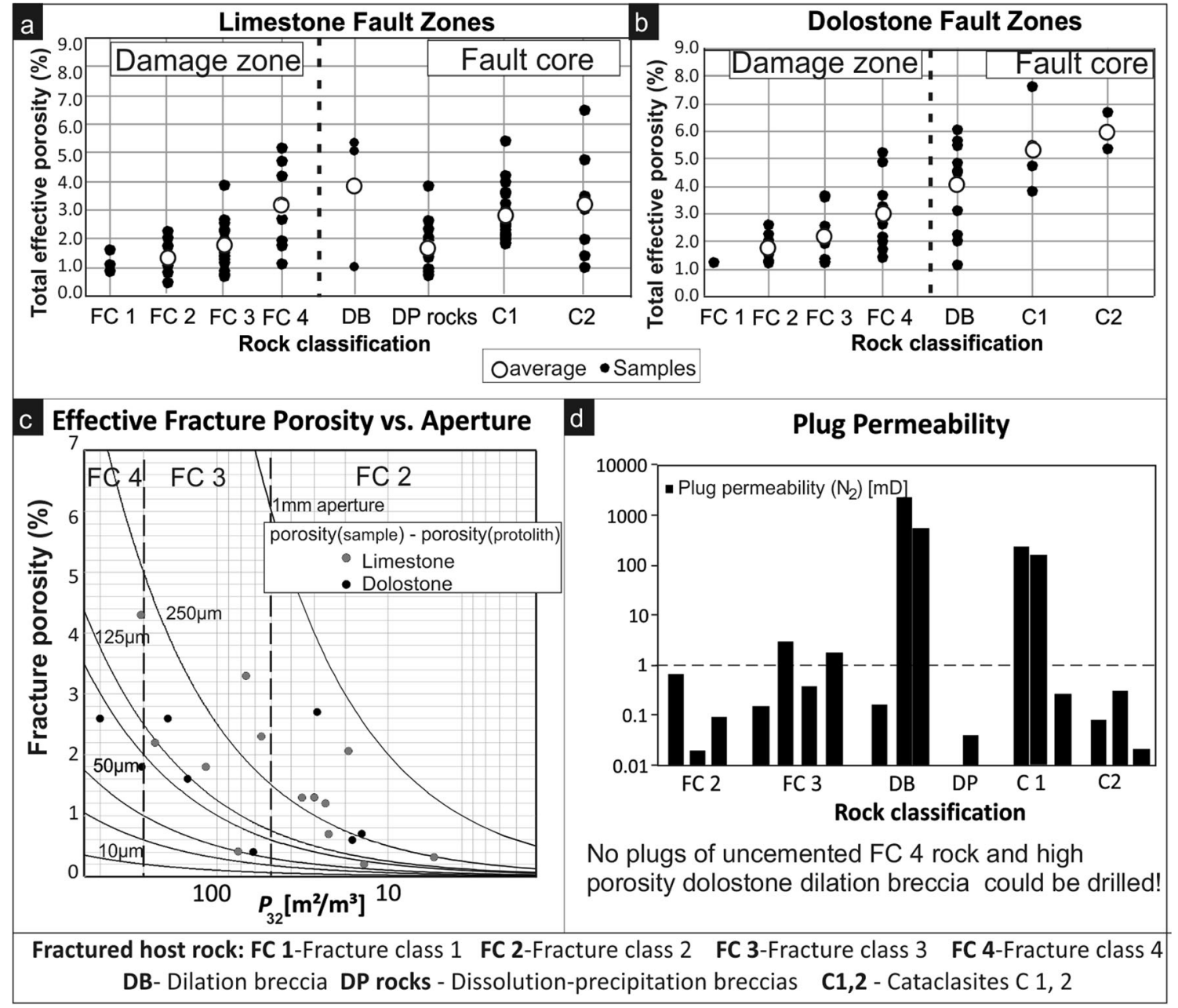

Fig. 10 Porosity/permeability data. a-b Porosity of limestone and dolostone fractured rock. There is an increase of $2 \%$ in the average porosity and permeability for dilation breccias and cataclasites, with high standard deviations due to selective cementation, grain and pore size variability, and secondary dissolution. c Fracture porosity as a function of fracture density; aperture adds at maximum a few $\%$ to total porosity. d Plug permeabilities are low $(<1 \mathrm{mD})$ for fractured rocks, fine grained cataclasites and DP breccias but significantly elevated for some cataclasites type $1(\mathrm{C} 1)$ and dilation breccias
Limestone dilation breccias are observed from faults A6 and A4. They show a different micro structural build-up as those from dolostones, with larger grains, less matrix, and less pronounced grain-size reduction. A6 dilation breccias contain a significant amount of open voids up to several $\mathrm{mm}$ wide. Breccias in A6 are close to the relict cave and are therefore affected by secondary dissolution.

Porosity and permeability. Dolostone dilation breccias have an average porosity of $3.9 \%$, with a standard deviation of 1.5 (Fig. 10b). This high spread in dilation breccia porosities is due to variable degrees of cementation. As no dolostone dilation breccia could be drilled because of the fragile nature of these rocks, the permeability of these rocks can only be estimated. Permeability in highly porous dilation breccias is expected to be significantly enhanced when compared to cataclasites and slightly fractured rock. Where cementation is pervasive (low-porosity dilation breccias), permeabilities can be expected to be low; however, no completely cemented dilation breccias were observed from thin sections.

Limestone dilation breccias of the fault A6 have 1,5 and $6.3 \%$ effective porosity (Fig. 10a). These significant differences in porosities of samples taken next to each other indicate that secondary dissolution is affecting dilation breccias. This is demonstrated by two plugs taken from the same hand specimen having permeabilities of 551 and 2,214 mD (Fig. 10d).

\section{Dissolution-precipitation breccias}

Lithology. Dissolution precipitation breccias (DP breccias) contain large portions of slickolites produced by dense networks of stylolites showing a wide spectrum of orientations. Stylolites are heterogeneously spaced at distances of few $\mathrm{mm}$ up to few $\mathrm{cm}$. These rocks additionally contain various proportions of calcite-cemented 
veins. Thin sections of DP breccias (Fig.91) show pervasive, multi-phase calcite-cemented veins at high angles to (sub-)parallel stylolites producing a clay-bearing, foliated fault rock. Clays (red to brownish layers) consist of mainly kaolinite, illite and chlorite minerals.

Porosity and permeability. DP fault rocks have a low average porosity of $1.7 \%$ with a standard deviation of 0.8 (Fig. 10a). The low porosity is a consequence of the pervasive cementation of these rocks and the passive accumulation of clay minerals within interconnected stylolites, although clay layers are accompanied by parallel micro fractures that carry some porosity. Plug permeability of DP breccias is low at $0.04 \mathrm{mD}$ (Fig. 10d).

\section{Cataclastic fault rocks}

Lithology. Type1 cataclastic rocks (example given in Fig. 9f) are fragment-supported rocks. Fine-grained matrix $(<20 \%)$ is distributed inhomogeneously or located in shear band-like zones throughout the rock. Angular host-rock fragments show significant variability in size ( $\mathrm{cm}$ to $\mathrm{mm}$ ) and bad sorting.

Type 2 cataclasites (Fig. 9e, h, j) are matrix-supported cataclasites. The average size of host-rock fragments is in general smaller than in type 1 , and advanced grain-size reduction-produced matrix particles with a grain size $<5 \mu \mathrm{m}$ (Fig. 9k). The matrix is completely cemented or recrystallized (Fig. 9i), resulting in very cohesive rocks.

Porosity and permeability. Porosity in cataclastic rocks is carried by the cataclastic matrix and has a mean of $2.9 \%$ with a standard deviation of 1.1 for type 1 and a mean of $4.1 \%$ with a standard deviation of 1.9 for type 2 cataclasites (limestone and dolostone), respectively. Standard deviations within both cataclasite classes are very high, showing that cataclasite porosities are not following the macroscopic criteria of classification. Several factors control the porosity of cataclasites: (1) the size of matrix grains and associated pores, (2) the degree of cementation or recrystallization and, for limestone cataclasites, (3) secondary dissolution.

For dolostone cataclasites, similar to dilation breccias, the crucial factor is cementation, as it potentially destroys the matrix-bound porosity. Type 1 and type 2 cataclasites (Fig. 10b), whether from low-displacement A1 fault or from high-displacement A2 fault, contain significant matrix porosity, although there is microscopic evidence for partial cementation with calcite. Pore diameters within each cataclasite may vary from several $\mu \mathrm{m}$ to tens of $\mu \mathrm{m}$ (Fig. 9e, f), still producing effective porosities $>4 \%$.

Limestone cataclasites type 1 have an average porosity of $2.8 \%$ with a standard deviation of 0.8 , type 2 cataclasites have an average porosity of $3.2 \%$ with a standard deviation of 1.8 . Thin sections of type 2 cataclasites (Fig. 9hi) show that the very low porosities result from a high proportion of completely cemented or recrystallized matrix, leaving pores $<<5 \mu \mathrm{m}$ in size with the contribution of few isolated fractures. A similar mechanism can be inferred for cohesive cataclasites type 1 with low porosities. Secondary dissolution is evident from thin-section and hand-specimens with cataclastic matrix and larger grains partially dissolved (Fig. 9j, k). The concept of karstified cataclasites is supported by the fact that rock samples taken next to each other and showing almost identical microstructures reveal differences of $3 \%$ in their porosities. Karstification is restricted to distinct areas within the cataclasites and is not pervasive (even on the sample scale).

Plug permeabilities of low-porosity cataclasitic rocks type 1 and 2 are $0.7 \mathrm{mD}$ (porosity $2 \%$ ), $0.3 \mathrm{mD}$ (porosity $1 \%$ ) and $0.03 \mathrm{mD}$ ( $2 \%$ porosity). This illustrates that pores within most of the cataclasites are too small to result in any significant permeability. A single sample from fault A6 classified as cataclasite type 1 shows a significantly elevated permeability of $228 \mathrm{mD}$ (porosity $8 \%$ ). This fault rock was sampled next to high-permeability dilation breccias $(2,214 \mathrm{mD})$.

\section{Discussion}

\section{Generation and hydrogeological significance of fault-cores}

Fault zones show significant differences and complexities in the build-up of their fault cores. These differences, even on a cm-scale, can be explained in consideration of the fault-zone model after Childs et al. (2009), where faults are described as evolving from irregular, segmented fault surfaces that get connected and bypassed during increase of displacement. Faultzone complexity and ultimately fault-rock thickness are then directly controlled by fault geometry, status of segmentation/ linkage, and total displacement. Fault zone properties can vary significantly within the same lithological unit. This explains why the studied faults of the same deformation stage show (1) differences in the distribution and volume of fault rock along their fault cores, (2) lenses of low-strain rocks next to highstrain rocks along the fault core, and (3) breccia zones that are distributed inhomogeneously and show weak lateral continuity. Four types of deformation processes are evident from the faults: (1) cataclasis, (2) rock pulverization, (3) pressure solution and (4) fracturing.

Cataclasis in its strict sense, with grain-size reduction due to localized shear, grain translation and rolling and rounding of grains, is restricted to zones of localized, higher strain at master faults and secondary fault planes in some cases marked by cataclasites type 2 rocks. These show grain-size reduction by comminution (producing high volumes of fine-grained matrix), shear fracturing and chipping, resembling the "mature" cataclasite fabric described by Billi (2010). Cataclasites type 2 are always very cohesive rocks, with complete cementation or eventually recrystallization (Smith et al. 2011) of the finegrained matrix. Cataclasites type 1 show only localized 
portions of fine-grained matrix, indicating that these rocks are formed by (intra-granular) extensional fracturing and in-situ grain-size reduction by crushing of entire intermediate components with increasing deformation (Schröckenfuchs et al. 2015). This results in a heterogeneous micro-structural build-up, which the authors think is also responsible for the variable porosities.

From plug permeabilities (Fig. 11b) it is evident that finegrained cataclasites have to be regarded as impermeable fault rocks, as plug permeabilities range from $0.5 \mathrm{mD}$ down to $0.01 \mathrm{mD}$. One sample shows significantly elevated permeability (Fig. 11b) due to secondary dissolution. The present data set unfortunately does not allow to clarify whether cataclasites with higher porosities have elevated permeabilities and if yes, whether a process different from secondary dissolution could be responsible for that; however, examples from the literature treat fine-grained cataclastic rocks as impermeable (Agosta and Kirschner 2003; Agosta et al. 2007; Agosta 2008; Storti et al. 2003).

The largest volumes of dilation breccias are observed from fault $\mathrm{A} 2$ in dolostone. The formation of dilation breccias here is not by hydraulic fracturing with increased fluid pressure (Tarasewicz et al. 2005), but by rock pulverization without a major contribution of fluids (Schröckenfuchs et al. 2015). Dilation breccias formed by rock pulverization during dynamic earthquake rupturing are characterized by sedimentation of fine-grained particles within open voids. They lack crack-seal textures and contain large volumes of uncemented, intensely fractured rock. A similar mechanism has been proposed for dolostone faults by Fondriest et al. (2015). In terms of permeability, dilation breccias in fault A2 represent zones of significantly elevated porosity and permeability during active faulting. Secondary cementation, observed from all dilation breccias, did not occur in a fully saturated environment. This is why connectivity and volume of open voids and pores remaining after the partial cementation of dilation breccias is difficult to determine from both outcrop and micro-scale but could explain the high spread of porosities within dilation breccias. Due to the low cohesion and bad mechanical

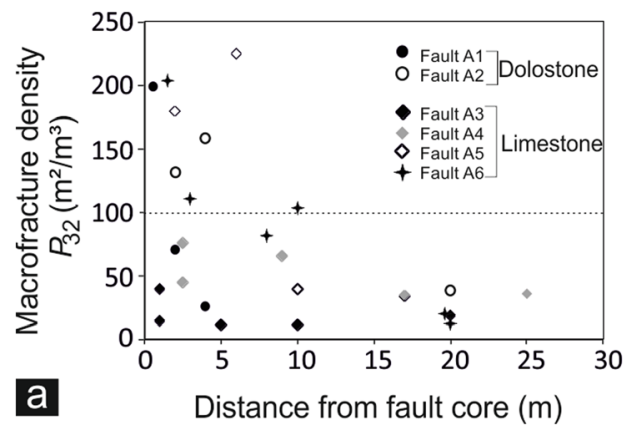

Fig. 11 a Density of macro-fractures with distance from fault core. The highest fracture density is always close to the fault core. Zones with high fracture densities can be up to several meters thick and seem to correlate with the displacement magnitude of faults. b Plug permeabilities of properties of this type of rock, no plugs could be drilled for measurements. From hand specimens and thin sections (see also Schröckenfuchs et al. 2015), the authors interpret dolostone dilation breccias as permeable units.

Dilation breccias observed along limestone faults (no rock pulverization) are interpreted to have formed along dilational jogs along the faults (Tarasewicz et al. 2005) or due to concentration of strain at initial asperities (Childs et al. 2009), causing localized high-density fracturing of the host rock (brecciation). As demonstrated by plugs (Fig. 11b), the permeability of this type of breccia is $>1,000 \mathrm{mD}$, which comes from a high initial permeability as well as from preferentially captured dissolutional weathering, proven by dissolution cavities. If these types of breccias show cementation of the pore space created by brecciation or grinding with further displacement along the fault zone (Fig. $11 \mathrm{~b}$ cemented, sheared dilation breccia), the permeability is strongly reduced $(0.2 \mathrm{mD})$.

Pressure solution in terms of subordinate slickolites is observed from all limestone faults. Fault A5 proves that pressure solution has the potential to produce fault rocks which may have a significant impact on bulk permeability. These rocks form by dissolution of the carbonate protolith and reprecipitation within connected fractures. They correlate in their microstructures with rocks formed by aseismic pressure-solution creep deformation (Gratier 2011; Tesei et al. 2013). The sealing capacity of these rocks depends on the volume of DP breccias generated. In fault A5, DP breccias are restricted to several tens of centimeter-thick zones associated with branching secondary fault planes. DP breccias display localized barriers close to the fault core but major portions of the damage zone remote from the fault core are not affected and remain permeable.

The mechanics of fracture initiation and propagation are beyond the scope of this work. For low-porosity $(<10 \%)$ and permeability $\left(10^{-15} \mathrm{~m}^{2}\right)$ rocks, bulk porosity and permeability are primarily controlled by the fracture-network properties, where individual fractures with a moderate aperture $(\sim 100-250 \mu \mathrm{m})$ can still control local permeability (Bense et al. 2013). The available data show that the increase of

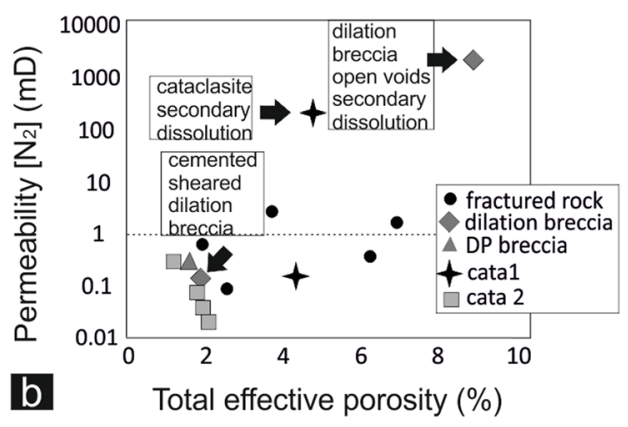

fractured host rock are low since plugs do not sample fractures. Cataclasite $\mathrm{C} 1$ and 2, and DP breccias have low permeabilities, whereas dilation breccias and karstified cataclasites show high permeabilities 
fracture densities towards the fault core is neither continuous nor homogenous. In some faults, fracture densities increase significantly at a distance of about $10 \mathrm{~m}$ from the fault core, whereas in others, compartments with lower fracture densities can occur very close to the master fault or even in direct contact with it (Fig. 11a). Although the authors have no quantified hydraulic data of highly fractured rock, as samples or plugs will only deliver the very low matrix permeability of the host rock (Fig. 11b), networks of macrofractures that are interconnected and uncemented are interpreted to be an important contribution to flow along fault zones. Additionally, the authors interpret systematic Riedel- and fault-parallel fractures with highest lengths as features with higher permeabilities, which is supported by Agosta et al. (2010) and Jourde et al. (2002) who show significant channelling of flow into focused flow paths along major, fault-parallel fractures.

\section{Fault-zone classification and hydrogeological properties}

The investigated fault zones are representative for faults resulting from the D3 deformation phase in the Hochschwab carbonate massif. Four characteristic types of fault zones (Fig. 12) can be distinguished.

1. Faults with minor fault cores are conduits (represented by fault A3). The fault core contains a continuous principal slip plane, but only very localized, disconnected rather than continuous compartments of cataclastic fault rock.
Fracture-density increase from the outer damage zone towards the fault core is restricted (Fig. 11a). Fractures are pervasively connected and uncemented with systematic Riedel shear-parallel fractures. Relict karst-cave fill proves that such a fault despite its low fracture density and minor fault rock content still has the potential to form a high-permeability streak. Incipient karstification most likely has been supported by significant permeability in a well-connected fracture network within the damage zone. Despite the low displacement and subordinate importance in the regional structural context, the hydrogeological footprint of this type of fault as pathway within the aquifer system should not be underestimated.

2. Faults with persistent, single-stranded, permeable fault cores are conduits, characteristic for medium size faults in limestone (faults A4 and A6). The internal architecture of the fault core is complex, containing a single principal cataclastic zone which is vertically and laterally continuous but variable in thickness, as well as multiple lenticular bodies of brecciated and highly fractured rocks along secondary anastomosing and interconnected fault planes. Cataclastic fault rocks host the principal slip plane (master fault), with strain localized within thin layers of mature cataclastic rocks. Fractured host rock shows more heterogeneity with respect to fracture density and distribution when compared to faults of type 1 . Fracture densities increase by a factor of 2 from FC 2 to FC 3 and a factor of 10 from FC 2 to FC 4, respectively. Fractured host rock close
Fig. 12 The four types of fault zones that have been differentiated in this study. Type 1 and 2 fault zones can be regarded as conduits in the aquifer, where fluid flow is located close to or within fault cores within highly fractured and brecciated rocks. Thick and strongly cemented fault cores have the potential to form (local) barriers to across-fault flow (fault zone type 3).

However, enough uncemented fracture volume remote from the core is available for fluid flow. Fault zones with multiplestranded fault cores of type 4 from dolostones can be regarded as conduits, containing the largest volume of intensely fractured, uncemented rock and dilation breccias

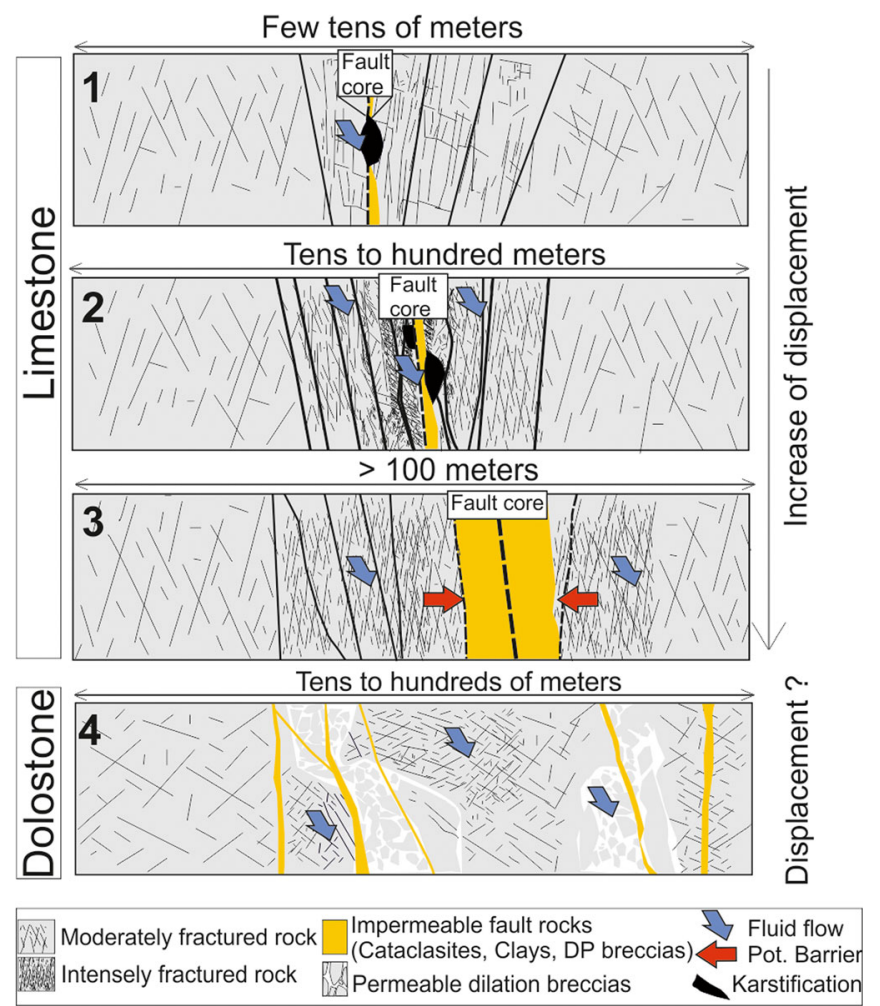


to fault cores shows asymmetry with respect to the master fault and can be FC 2, FC 3 or FC 4, demonstrating a nonsystematic variation of fracture density with distance from fault core (Fig. 11a). Fracture patterns are anisotropic where Riedel shears and Riedel-parallel fractures are present. Independent of fracture class, fractures form connected networks. Relicts of karst pipes (A4) and caves (A6) adjacent to primary and secondary fault planes indicate that the fault core rather than the fractured damage zone is subjected to secondary dissolution, which is due to the presence of brecciated host rock and a high-density network of fault planes. Faults of this type are considered to act as hydrogeological pathways, with highestpermeability compartments adjacent to cataclastic zones where most of the brecciated and intensely fractured rocks are located.

3. Faults with persistent, single-stranded, impermeable fault cores are conduit-barrier systems formed by large fault displacement. They are represented by fault A5. The cataclastic fault core shows a strongly cemented type 2 cataclasite containing the master fault. At the transition from damage zone to the several meter-thick cataclastic fault core, cemented and clay-bearing breccias are present. These are restricted to narrow, some tens of centimeters thick, zones along secondary fault planes branching from the master fault. Cementation is the result of pressure solution of the protolith, with dissolved calcite precipitated within pervasive veins and cracks. The clay component of breccias derives from primary impurities within the limestone at this location or from shales smeared into the fault. Fracture densities throughout the damage zone show a similar heterogeneous distribution as faults of type 2 ; however, the overall damage zone thickness is at least doubled. From field evidence, this type of fault is seen as having the potential to act as a conduit-barrier system as orthogonal fluid flow across the fault core could be inhibited. Fluid migration is fault-parallel within the fractured host rock. The deformation history of such large-scale faults may be very complex; as a consequence, the hydrogeological characterization should be done on a case-by-case basis.

4. Faults with multiple-stranded fault cores in dolostones act as conduits and are represented by faults A1 and A2. A differentiation into a single fault core and a damage zone is not adequate for this type of fault as they have multiple branched shear zones hosting a complex assemblage of cataclastic strands and dilation breccias. Dilation breccias and very intensely fractured host rock are distributed over wide parts along the fault zones and make up large volumes of rock. Principal slip planes and cataclastic strands show no such lateral continuities as observed in the limestone faults, where they can be tracked over several hundred meters. This structural build-up clearly contradicts a hydrogeological characterization in the sense of a single fault core/damage zone model but is better described with a multiple-stranded fault-core model (Faulkner et al. 2010). The large volumes of highly fractured, uncemented host rock (up to $30 \%$ ) are seen as highly permeable domains along the fault. Varying deformation mechanisms have to be invoked to explain the differences in structural build-up and fault cores of limestone and dolostone faults (see 'Generation and hydrogeological significance of fault-cores'). Our study indicates that in addition lithological contrasts govern fault-zone architecture and deformation processes. This is in line with other authors (e.g. Peacock and Sanderson 1992; Schöpfer et al. 2006) who showed that initial fault geometry is also controlled by mechanical heterogeneity and individual rheology of the host rock. This is best illustrated by the fault $\mathrm{A} 2$, which is located at the contact of limestone and dolostone. The majority of the deformation is focused within the dolostone, whereas the limestone adjacent to the fault contains neither pulverized rocks nor multiple-stranded cataclasites. The authors suggest that primary microfractures within the dolostone allow for (1) overall significantly elevated fracture densities in dolostone faults compared to limestone faults, independent of deformation processes or magnitude of displacement, and (2) the formation of multiple cataclastic strands. On the contrary, only limestones deform by pressure-solution creep. For limestone fault-zone types, the thickness of cataclasite and degree of cementation determine whether a fault acts as a conduit or barrier. The degree of karstification, which has been observed frequently in outcrops and is able to produce superposed flow conduits of extreme capacity, will, at least partly, be controlled by the fault-zone architecture and the resulting permeability distribution. In dolostone faultzones, highly permeable compartments of fractured host rock and dilation breccias are interconnected. Cataclasite strands, representing localized impermeable features, create permeability anisotropies and potential channel fluid flow within the fractured rock. From field evidence, it becomes obvious that (1) laterally and vertically every fault exhibits (significant) differences in the amount of cataclasites, brecciated rock and fracture densities, even over fairly short distances, and (2) the fault zones investigated cover a wide spectrum of possible fault-zone anatomies related to the D3 deformation stage within the study area. For the regional scale, it becomes important to note that the individual fault differences are of minor significance for the behaviour of the entire aquifer system.

\section{Fault zones on a regional scale: flow conduits or barriers?}

The variability in the fault-zone architecture captures a wide range of possible outcomes of a particular deformation event 
affecting distinct lithologies. Permeable damage zones as well as both permeable and impermeable fault cores, on a scale of a meter to tens of meters, can be defined. On this scale, impermeable portions of the fault core for fault zones type 1,2 and 4 disappear and re-appear, the fault core in addition is cross-cut by dissolution features allowing cross fault flow. These faults are considered conduits on both the outcrop and the regional scale. On the contrary, the fault core of fault-zone type 3 may on an outcrop scale act as a local barrier leading to focusing of flow within permeable volumes adjoining the fault core. Regional field work indicates that increasing the scale, the definition of an impermeable fault core may break down as the fault may be cut and offset by other faults; thus, flow across the fault may not be excluded.

The limestone watershed of the Hochschwab massif is characterized by intense and deep-reaching karstification (Plan 2002). The concept of a permeable and interconnected faultzone network at the regional scale with only subordinate, locally restricted fault-core barriers is supported by the distribution of springs in the watershed which is the focus of this study. Springs emerge at the base of the carbonate massif where impermeable units form the stratigraphic or tectonic base and the water table intersects the topography. Infiltration of water from rain or snowmelt through the thick vadose zone in limestone happens along permeable portions of the sub-vertical fault-network. Barriers in extensive fault cores only locally focus flow along the fault zone. Intense precipitation events (thunderstorms, rapid snow melt due to warm winds) may exceed the transmissive capacity of the fault-zone network and discharge may occur where permeable streaks or karst conduits intersect the valley flanks; however, the majority of percolation still takes place downwards to a regional water table and then laterally following the pressure differential within the interconnected fault network towards the springs.

\section{Depth effect on porosity and permeability of fault zones}

All investigated portions of the fault zones are located within the present-day vadose zone but at a maximum of a few hundred meters from the present-day water table. Outcrops in limestones show an overburden of several hundred meters, whereas dolostone outcrops, on the other hand, are located at a higher elevation without significant overburden. A possible reduction of fracture aperture and thus porosity or permeability down to the water table, cannot be assessed. Fracture apertures may show a decrease downwards to the phreatic zone, but fault zones are expected to retain volumes of elevated permeabilities compared to the host rock. The removal of rock due to glacial erosion and the exhumation of fault outcrops along the valley flanks may have slightly increased fracture aperture and consequently porosity and permeability.

In general, the outcrops are considered representative with respect to the parameters of the fault-zone network in the vadose zone relatively close to the water table. Available data do not allow for a clear picture of parameters of the fault-zone network in the phreatic zone, whereas evidence from outcrops distributed over the Ring Valley, on the other hand, indicates that some of the observed karst features developed under former phreatic conditions. Therefore it is assumed that processes of karstification in the present-day phreatic zone produce similar features.

\section{Fault-rock volume and storage capacity}

The high discharge ratio of the Kläffer spring testifies to the overall low storage capacity of the limestone fault/karst system, which is in line with the results of this study. Matrix porosity of the host rock is negligible, with small pore throats being an additional limitation. Locally, beneficial lithologies and (micro-)joints away from specified fault zones may add to the storage capacity of the host rock.

It is assumed that, though considered to be quite limited on absolute terms, a significant part of the storage capacity of the Hochschwab limestone karst aquifer resides within pores, fractures and karst features of an interconnected fault-zone network. In order to verify this assumption and to relate the storage capacity to spring discharge, a Monte-Carlo simulation of a conceptual fault-zone network (see Figure S2 and Table S1 of the ESM) was performed.

The underlying assumption is a fault-zone network between the base and top spring of the Kläffer spring system at maximum fill ( $\sim 100 \mathrm{~m}$; Plan et al. 2010) just before the onset of the winter months with no additional recharge during the following cold months since precipitation mostly falls as snow. In order to verify whether a fault-zone network with the parameters resulting from this study on one hand could be assumed representative for the entire watershed and on the other hand may be able to supply the winter base flow to the above springs, or whether significant additional storage volume has to be taken into account, a range of percentage of fault rock and corresponding average porosities was chosen as input. The range of gross-rock volume reflects the uncertainty in the exact size of the watershed.

Results indicate that in the majority of realizations the simulated fault-zone network is either the sole contributor or contributes significantly to the storage capacity. Assuming only very minor contribution of additional storage from the host rock, a minimum of around $5 \%$ of fault-zone volume over the whole catchment area is required to deliver the base discharge of the main spring system, a value which is in line with the observed spatial distribution and density of fault zones across the catchment. The size of the catchment and the reduced surface runoff due to its karstic characteristics would explain that, in such a scenario, a relatively small percentage of fault-rock volume is sufficient to provide the storage capacity to sustain base flow. 
Due to the higher storage capacity of the joint system in the dolostone host rock, the effect of precipitation events on spring discharge is in general more dampened than in faulted and karstified limestone. For lack of sufficient data, it was at this stage not possible to define and verify parameters of a conceptual fault-zone network on a regional scale. It is however interesting to note that the Pfannbauern spring, which discharges from a dolostone watershed, shows a deviating behavior when simulated base flow and measured discharge are compared (Nachtnebel et al. 2012), which possibly indicates the superposed effect of high-permeability streaks (fault zones).

\section{Conclusions}

The present study of shallow crustal faults gives an integrated insight into the structurally controlled characteristics of smallto medium-size faults which form first-order permeability structures within the economically important Hochschwab karst massif (Austria).

- This study confirms that in massive, low-porosity carbonates that lack pervasive planar features such as bedding, faults form the most important corridors for potential fluid infiltration, migration and karstification.

- Our data illustrate significant differences in the architectural build-up of fault zones in dolostone (multiplestranded cataclastic fault cores of weak lateral continuity, high volumes of intensely fractured rock) and limestone (laterally distinct, single-stranded fault cores, Riedel-shear fractures dominating fracture patterns).

- Low-permeability $(<1 \mathrm{mD})$ cataclastic fault rocks are only abundant enough in high-displacement faults to form barriers on an outcrop scale.

- Fault cores of low to medium displacement faults contain domains of brecciated and highly fractured rocks along their lateral and vertical extension and are therefore seen as conduits. This interpretation is underlined by karstification features within the faults that are predominantly located along the fault cores.

- Fault zones are accompanied by significant fault-parallel volumes of fractured host rock. Fracture densities vary by a factor of up to 10. Although macro-fractures are seen as prominent flow-controlling features, methods used do not allow for a proper quantification of their hydrogeological properties.

- Faults are seen as flow conduits on a regional scale. Portions of impermeable fault core are not expected to be continuous and persistent enough to have a regional impact. Monte Carlo simulation of a conceptual fault network supports the view that most of the storage capacity in the limestones resides within the pore volume of the faultzone network.
Acknowledgments Open access funding provided by University of Vienna. We thank Wolfgang Zerobin and Gerhard Kuschnig of the Vienna Waterworks for their long-time cooperation with the University of Vienna and their great support for research in hydrogeology. We thank the staff of the Vienna Waterworks for their support during the fieldwork and Lukas Plan for sharing his expertise on karst and caves at the Hochschwab as well as Albert Kostner for fruitful discussions and his great help on improving the English. The paper benefited from the constructive and very helpful comments of the journal editor and associate editor and from the detailed reviews of Andrea Billi and two anonymous reviewers. This work was funded by the Vienna Waterworks (Contract FA 536018 Hydro Faults).

Open Access This article is distributed under the terms of the Creative Commons Attribution 4.0 International License (http:// creativecommons.org/licenses/by/4.0/), which permits unrestricted use, distribution, and reproduction in any medium, provided you give appropriate credit to the original author(s) and the source, provide a link to the Creative Commons license, and indicate if changes were made.

\section{References}

Agosta F (2008) Fluid flow properties of basin-bounding normal faults in platform carbonates, Fucino Basin, central Italy. Geol Soc Lond Spec Publ 299:277-291

Agosta F, Kirschner DL (2003) Fluid conduits in carbonate-hosted seismogenic normal faults of central Italy. J Geophys Res 108: 2221. doi:10.1029/2002JB002013

Agosta F, Prasad M, Aydin A (2007) Physical properties of carbonate fault rocks, Fucino Basin (central Italy): implications for fault seal in platform carbonates. Geofluids 7:19-32

Agosta F, Alessandroni M, Antonellini M et al (2010) From fractures to flow: a quantitative analysis of an outcropping carbonate reservoir. Tectonophysics 490:197-213

Agosta F, Ruano P, Rustichelli A et al (2012) Inner structure and deformation mechanisms of normal faults in conglomerates and carbonate grainstones (Granada Basin, Betic Cordillera Spain): inferences on fault permeability. J Struct Geol 45:4-20

Antonellini M, Cilona A, Tondi E et al (2014) Fluid flow numerical experiments of faulted porous carbonates, northwest Sicily (Italy). Mar Pet Geol 55:186-201

Austrian Standards (1999) ÖNORM EN 1936:1999: determination of real density and apparent density, and of total and open porosity. https://www.austrian-standards.at. Accessed 01 February 2012

Aydin A (2000) Fractures, faults, and hydrocarbon entrapment, migration and flow. Mar Pet Geol 17:797-814

Balsamo F, Storti F (2010) Grain size and permeability evolution of softsediment extensional sub-seismic and seismic fault zones in highporosity sediments from the Crotone basin, southern Apennines, Italy. Mar Pet Geol 27:822-837

Baqués V, Travé A, Benedicto A et al (2010) Relationships between carbonate fault rocks and fluid flow regime during propagation of the Neogene extensional faults of the Penedès basin (Catalan Coastal Ranges, NE Spain). J Geochem Explor 106:24-33

Bense VF, Person M (2006) Faults as conduit-barrier systems to fluid flow in siliciclastic sedimentary aquifers. Water Resour Res 42: W0542. doi:10.1029/2005WR004480

Bense VF, Gleeson T, Loveless SE et al (2013) Fault zone hydrogeology. Earth Sci Rev 127:171-192

Billi A (2005a) Grain size distribution and thickness of breccia and gouge zones from thin $(<1 \mathrm{~m})$ strike-slip fault cores in limestones. J Struct Geol 27:1823-1837 
Billi A (2005b) Attributes and influence on fluid flow of fractures in foreland carbonates of southern Italy. J Struct Geol 27:1630-1643

Billi A (2010) Microtectonics of low-P low-T carbonate fault rocks. J Struct Geol 32:1392-1402. doi:10.1016/j.jsg.2009.05.007

Billi A, Di Toro G (2008) Fault-related carbonate rocks and earthquake indicators: recent advances and future trends. In: Landowe SJ, Hammler GM (eds) Structural geology: new research. Nova, Hauppauge, NY

Billi A, Storti F (2004) Fractal distribution of particle size in carbonate cataclastic rocks from the core of a regional strike-slip fault zone. Tectonophysics 384:115-128. doi:10.1016/j.tecto.2004.03.015

Billi A, Salvini F, Storti F (2003) The damage zone-fault core transition in carbonate rocks: implications for fault growth, structure and permeability. J Struct Geol 25:1779-1794. doi:10.1016/S0191-8141(03) 00037-3

Billi A, Valle A, Brilli M et al (2007) Fracture-controlled fluid circulation and dissolutional weathering in sinkhole-prone carbonate rocks from central Italy. J Struct Geol 29:385-395

Billi A, Primavera P, Michele S et al (2008) Minimal mass transfer across dolomitic granular fault cores. Geochem Geophys Geosys 9, Q01001. doi:10.1029/2007GC001752

Bonson CG, Childs C, Walsh J et al (2007) Geometric and kinematic controls on the internal structure of a large normal fault in massive limestones: the Maghlaq Fault, Malta. J Struct Geol 29:336-354

Bryda G (2001) Geologische Kartierung im Hochschwabgebiet: Entscheidungshilfe zur Abgrenzung von Quelleinzugsgebieten [Geological map of the Hochschwab: decision guidance for the discrimination of spring catchments]. In: Mandl GW, Geologische Bundesanstalt Arbeitstagung 2001 [Geological workshop of the Geological Survey of Austria, report]. Geological Survey of Austria, Vienna

Caine JS, Evans JP, Forster CB (1996) Fault zone architecture and permeability structure. Geol 24:1025-1028

Celico F, Petrella E, Celico P (2006) Hydrogeological behaviour of some fault zones in a carbonate aquifer of southern Italy: an experimentally based model. Terra Nov. 18:308-313

Chester FM, Evans JP, Biegel LR (1993) Internal structure and weakening mechanism of the San Andreas Fault. J Geophys Res 98:771-786

Childs C, Manzocci T, Walsh JJ et al (2009) A geometric model of fault zone and fault rock thickness variations. J Struct Geol 31:117-127. doi:10.1016/j.jsg.2008.08.009

de Dreuzy JR, Davy P, Bour O (2002) Hydraulic properties of twodimensional random fracture networks following power law distributions of length and aperture. Water Res Res 38:12. doi:10.1029/ 2001WR001009

Decker K, Reiter F, (2001) Strukturgeologische Methoden zur Charakterisierung von Karstwasserwegen im Hochschwabmassiv [Structural methods for the characterization of karst water flow paths in the Hochschwab massif]. In: Mandl GW (ed) Geologische Bundesanstalt Arbeitstagung 2001 [Workshop of the Geological Survey of Austria 2001]. Conf. Proc., Geological Survey Austria, Vienna

Decker K, Peresson H, Faupl P (1994) Die miozäne Tektonik der östlichen Kalkalpen: Kinematik, Paläospannung und Deformationsaufteilung während der "lateralen Extrusion" der Zentralalpen [Miocene tectonics of the Eastern Alps: kinematics, paleostresses and deformation partitioning during the lateral extrusion of the central Alps]. Annu Rep Geol Surv Austria 137(1):5-18

Dershowitz WS, Herda HH (1992) Interpretation of fracture spacing and intensity. Proceedings of the 32nd US Symposium on Rock Mechanics (USRMS), Santa Fe, NM, American Rock Mechanics Assoc., Alexandria, VA, pp 757-766

Dor O, Ben-Zion Y, Rockwell T et al (2006) Pulverized rocks in the Mojave section of the San Andreas Fault Zone. Earth Plant Sci Lett 245:642-654

eHyd (2014) Abteilung Wasserhaushalt: Hydrographisches Zentralbüro im Bundesministerium für Land- und Forstwirtschaft, Umwelt und
Wasserwirtschaft [Department of Water Supply, Hydrographic Central Office, Federal Ministry of Agriculture and Forestry, Vienna]. http://ehyd.gv.at/. Accessed 30 September 2014

Eichhubl P, Davatzes N, Becker S (2009) Structural and diagenetic control of fluid migration and cementation along the Moab Fault, Utah. Am Assoc Pet Geol Bull 93:653-681. doi:10.1306/02180908080

Faulkner DR, Mitchel TM, Rutter EH et al (2008) On the structure and mechanical properties of large strike-slip faults. In: Wibberley CA J, Kurz W, Imber J et al (eds) Structure of fault zones: implications for mechanical and fluid-flow properties. Geol Soc Lond Spec Publ 299:139-150

Faulkner DR, Jackson CAL, Lunn RJ et al (2010) A review of recent developments concerning the structure, mechanics and fluid flow properties of fault zones. J Struct Geol 32:1557-1575. doi:10. 1016/j.jsg.2010.06.009

Fondriest M, Aretusini S, Di Toro G et al (2015) Fracturing and rock pulverization along an exhumed seismogenic fault zone in dolostone: The Foiana Fault Zone (Southern Alps, Italy). Tectonophysics 654:56-74

Frost E, Dolan J, Sammis C et al (2009) Progressive strain localization in a major strike-slip fault exhumed from midseismogenic depths: Structural observations from the Salzach-Ennstal-Mariazel Puchberg fault system, Austria. J Geophys Res 114. doi:10.1029/ 2008JB005763

Frost E, Dolan J, Ratschbacher et al (2011) Direct observation of fault zone structure at the brittle-ductile transition along the SalzachEnnstal-Mariazell-Puchberg fault system, Austrian Alps. J Geophys Res 116. doi:10.1029/2010JB007719

Gratier J-P (2011) Fault permeability and strength evolution related to fracturing and healing episodic processes (years to millennia): the role of pressure solution. Oil Gas Sci Technol 66(3):491-506. doi: $10.2516 /$ ogst $/ 2010014$

Guerriero V, Iannace A, Mazzoli S et al (2010) Quantifying uncertainties in multi-scale studies of fractured reservoir analogues: implemented statistical analysis of scan line data from carbonate rocks. J Struct Geol 32:1271-1278

Guerriero V, Mazzoli S, Iannace A et al (2013) A permeability model for naturally fractured carbonate reservoirs. Mar Pet Geol 40:115-134

Hausegger S, Kurz W, Rabitsch E et al (2010) Analysis of the internal structure of a carbonate damage zone: implications for the mechanisms of fault breccia formation and fluid flow. J Struct Geol 32: 1349-1362

Jourde H, Flodin EA, Aydin A et al (2002) Computing permeability of fault zones in eolian sandstone from outcrop measurements. Am Assoc Pet Geol Bull 86:1187-1200

Kim YS, Sanderson D (2009) Inferred fluid flow through fault damage zones based on the observation of stalactites in carbonate caves. J Struct Geol 32:1305-1316. doi:10.1016/j.jsg.2009.04.017

Korneva I, Tondi E, Agosta F et al (2014) Structural properties of fractured and faulted Cretaceous platform carbonates, Murge Plateau (southern Italy). Mar Pet Geol 57:312-326. doi:10.1016/j. marpetgeo.2014.05.004

Kuschnig G (2009) Forschungsansätze zur Bewältigung kommender Herausforderungen bei der Wasserversorgung von Großstädten [Research approaches and coping strategies for the water supply of major cities]. Workshop of the Geological Survey of Austria, Conf. Proc., Leoben, Austria, August 2009

Leray S, de Dreuzy JR, Bour O et al (2013) Numerical modeling of the productivity of vertical to shallowly dipping fractured zones in crystalline rocks. J Hydrol 481:64-75. doi:10.1016/j.jhydrol.2012.12. 014

Linzer HG, Ratschbacher L, Frisch W (1995) Transpressional collision structures in the upper crust: the fold-thrust belt of the Northern Calcareous Alps. Tectonophysics 242:41-61. doi:10.1016/00401951(94)00152-Y 
Linzer HG, Decker K, Peresson H et al (2002) Balancing lateral orogenic float of the Eastern Alps. Tectnonophysics 354:211-237. doi:10. 1016/S0040-1951(02)00337-2

Lunn RJ, Shipton ZK, Bright AM (2008) How can we improve estimates of bulk fault zone hydraulic properties? In: Wibberley CAJ, Kurz W, Imber J et al (eds) The internal structure of fault zones: implications for mechanical and fluid-flow properties. Geol Soc Lond Spec Publ 299:139-150 doi: 10.1144/SP299.14

Mandl GW, Bryda G, Kreuss O et al (2000) Karstwasserdynamik und Karstwasserschutz Hochschwab: Geologische Karte [Karst water dynamics and protection Hochschwab: geological map]. Endber. Geol. B. A., Vienna, 82 pp

Micarelli L, Moretti I, Jaubert M et al (2006) Fracture analysis in the south-western Corinth rift (Greece) and implications on fault hydraulic behavior. Tectonophysics 426:31-59

Mitchell TM, Faulkner DR (2008) Experimental measurements of permeability evolution during triaxial compression of initially intact crystalline rocks and implications for fluid flow in fault zones. $J$ Geophys Res Solid Earth 113(B11)

Mitchell TM, Faulkner DR (2009) The nature and origin of off-fault damage surrounding strike-slip fault zones with a wide range of displacements: a field study from the Atacama fault system, northern Chile. J Struct Geol 31:802-816

Mitchell TM, Faulkner DR (2012) Towards quantifying the matrix permeability of fault damage zones in low porosity rocks. Earth Planet Sci Lett 339-340:24-31

Mitchell TM, Ben-Zion Y, Shimamoto T (2011) Pulverized fault rocks and damage asymmetry along the Arima-Takatsuki Tectonic Line, Japan. Earth Planet Sci Lett 308:284-297

Nachtnebel HP, Senoner T, Stanzel P et al (2012) Climate change and impacts on water supply. WP4 Water Resour Rep, Institute of Water Management, Hydrology and Hydraulic Engineering (IWHW), Univ Nat Resour Life Sci, Vienna

Peacock DCP, Sanderson DJ (1992) Effects of layering and anisotropy on fault geometry. J Geol Soc 149:793-802

Peresson H, Decker K (1997) The Tertiary dynamics of the northern Eastern Alps (Austria): changing paleostresses in a collisional plate boundary. Tectonophysics 272:125-157

Petracchini L, Antonellini A, Billi A et al (2012) Fault development through fractured pelagic carbonates of the Cingoli anticline, Italy: possible analog for subsurface fluid-conductive fractures. J Struct Geol 45:21-37

Plan L (2002) Speläologisch-tektonische Charakterisierung der Karstwasserwege im Einzugsgebiet der bedeutendsten Quelle der Ostalpen (Kläfferquelle, Hochschwab) [Speleological and tectonic characterization of karstic flow paths in the catchment of one of the most important springs in the Eastern Alsp (Kläffer spring)]. MSc Thesis, Univ. Vienna, Austria

Plan L (2005) Factors controlling carbonate dissolution rates quantified in a field test in the Austrian Alps. Geomorphology 68:201-212

Plan L, Decker K (2006) Quantitative karst morphology of the Hochschwab plateau, Eastern Alps, Austria. Zeitung Geomorphol 147:29-56

Plan L, Decker K, Faber R et al (2009) Karst morphology and groundwater vulnerability of high alpine karst plateaus. Environ Geol 58: 285-297

Plan L, Kuschnig G, Stadler H (2010) Kläffer spring: the major spring of the Vienna water supply (Austria). In: Kresic N, Stevanovic Z (eds) Groundwater hydrology of springs. Elsevier, Amsterdam

Rath A, Exner U, Tschegg C et al (2011) Diagenetic control of deformation mechanisms in deformation bands in a carbonate grainstone. Am Assoc Pet Geol Bull 95:1369-1381

Ratschbacher L, Frisch W, Linzer HG et al (1991) Lateral extrusion in the eastern Alps, part II: structural analysis. Tectonics 10:257-271. doi: 10.1029/90TC02623
Rawling GC, Goodwin LB, Wilson JL (2001) Internal architecture, permeability structure, and hydrologic significance of contrasting faultzone types. Geol 27:43-46

Savage HM, Brodsky EE (2011) Collateral damage: evolution with displacement of fracture distribution and secondary fault strands in fault damage zones. J Geophys Res 116:2156-2202. doi:10.1029/ 2010JB007665

Schöpfer MPJ, Childs C, Walsh JJ (2006) Localisation of normal faults in multilayer sequences. J Struct Geol 28:816-833

Schröckenfuchs T, Bauer H, Grasemann B et al (2015) Rock pulverization and localization of a strike-slip fault zone in dolomite rocks [Salzach-Ennstal-Mariazell-Puchberg fault, Austria]. J Struct Geol 78:67-85

Schulz SE, Evans JP (2000) Mesoscopic structure of the punchbowl fault, southern California, and the geological and geophysical structure of active faults. J Struct Geol 22:913-930

Shipton ZK, Cowie PA (2001) Damage zone and slip surface evolution over micron to $\mathrm{km}$ scales in high porosity Navajo sandstone, Utah. J Struct Geol 23:1825-1844. doi:10.1016/S0191-8141

Shipton ZK, Cowie PA (2003) A conceptual model for the origin of fault damage zone structures in high-porosity sandstone. J Struct Geol 25: 333-344

Shipton Z, Soden A, Kirkpatrick J et al (2006) How thick is a fault? Fault displacement-thickness scaling revisited. In: Abercrombie R, McGarr A, Toro GD et al (eds) Earthquakes: radiated energy and the physics of faulting. AGU Monograph Series 170. AGU, Washington, DC, pp 193-198

Sibson RH (1977) Fault rocks and fault mechanism. J Geol Soc Lond 133:191-213

Sibson RH (1986) Brecciation processes in fault zones: inferences from earthquake rupturing. Pure Appl Geophys 124:159-175

Smith SAF, Billi A, Di Toro G et al (2011) Principal slip zones in limestone: microstructural characterization and implications for the seismic cycle (Tre Monti fault, central Apennines, Italy). Pure Appl Geophys 168:2365-2393

Storti F, Billi A, Salvini F (2003) Particle size distributions in natural carbonate fault rocks: insights for non-self-similar cataclasis. Earth Plant Sci Lett 206(1-2):173-186

Tarasewicz JPT, Woodcock NH, Dickson JAD (2005) Carbonate dilatation breccias: examples from the damage zone to the Dent Fault, northwest England. Geol Soc Am Bull 117:736-745

Tesei T, Collettini C, Viti C et al (2013) Fault architecture and deformation mechanisms in exhumed analogues of seismogenic-bearing thrusts. J Struct Geol 55:167-181

Tollmann A (1976) Der Bau der Nördlichen Kalkalpen. Monographie der Nördlichen Kalkalpen [Geological build-up of the Northern Calcareous Alps. Monograph of the Northern Alps], 3rd edn. Deiticke, Vienna

Tondi E, Antonellini M, Aydin A et al (2006) The roles of deformation bands and pressure solution seams in fault development in carbonate grainstones of Majella Mountain, Italy. J Struct Geol 28: 376-391

Walker RJ, Holdsworth RE, Armitage PJ et al (2013) Fault zone permeability structure evolution in basalts. Geology 41(1):59-62. doi:10. 1130/G33508.1

Wibberley CAJ, Shimamoto T (2003) Internal structure and permeability of major strike-slip fault zones: the Median Tectonic Line in Mie Prefecture, southwest Japan. J Struct Geol 25:59-78

Wibberley CAJ, Yielding G, Di Toro G (2008): Recent advances in the understanding of fault zone internal structure: a review. In: Wibberley CAJ, Kurz W, Imber J et al (eds) The internal structure of fault zones: implications for mechanical and fluid-flow properties. Geological Society London, London

Woodcock NH, Mort K (2008) Classification of fault breccias and related fault rocks. Geol Mag 145(3):435-440 